\title{
Mechanisms of degassing at Nevado del Ruiz volcano, Colombia
}

\author{
J. STIX ${ }^{1}$, G. D. LAYNE² \& S. N. WILLIAMS ${ }^{3}$ \\ ${ }^{1}$ Department of Earth and Planetary Sciences, McGill University, 3450 University Street, Montreal, Quebec H3A 2A7, \\ Canada (e-mail: stix@eps.mcgill.ca) \\ ${ }^{2}$ Department of Geology and Geophysics, Woods Hole Oceanographic Institution, Woods Hole, MA 02543-1541, USA \\ ${ }^{3}$ Department of Geology, Arizona State University, Tempe, AZ 85287-1404, USA
}

\begin{abstract}
Nevado del Ruiz volcano is an andesite stratovolcano located in the northern Andes of Colombia. The volcano erupted on 11 September 1985, 13 November 1985, and 1 September 1989. The last two eruptions emitted juvenile solid material. This paper examines the volatile and light lithophile trace element contents of melt inclusions and matrix glasses from this juvenile material, and proposes a model for degassing within the volcano. Major element distributions in the glasses show two evolutionary trends, with subsidiary points that lie between the two trends. The data suggest the existence of two separate magmas, which have interacted, mingled, and mixed during their ascent and eruption. Water contents in melt inclusions, as determined by secondary ionization mass spectrometric analysis, are generally low, averaging between 1.6 and 3.3 wt.\%. Halogen concentrations in the glasses range from 400 to $1200 \mathrm{ppm}$ for fluorine and from 1100 to $1500 \mathrm{ppm}$ for chlorine. Sulphur contents are low, not exceeding $500 \mathrm{ppm}$, with most glasses containing $<200 \mathrm{ppm}$. Lithium concentrations range from 20 to $40 \mathrm{ppm}$, beryllium from 1.5 to $2 \mathrm{ppm}$, and boron exhibits high variability from 30 to $100 \mathrm{ppm}$. The only significant difference between melt inclusions and matrix glasses is for water, with matrix glasses having significantly lower concentrations $(<0.5 \mathrm{wt} . \%)$ than the melt inclusions. The generally elevated concentrations of boron in the magma may be a consequence of enrichment in the source region of the magma, i.e. by subduction of altered oceanic crust and/or sediments. Yet the large degree of boron heterogeneity in both melt inclusions and matrix glasses necessitates subsequent addition of boron at shallower depths as well, by the assimilation of crustal sedimentary rocks or by interaction with hydrothermal fluids. Evidence for pre-eruptive magma emplacement at shallow levels is provided by (1) anhydrous mineral assemblages of plagioclase and pyroxene, (2) high silica contents of glasses, and (3) low water contents in melt inclusions. When combined, these observations suggest a period of magma residence at shallow depths, probably $<3 \mathrm{~km}$ beneath the summit of the volcano. A multistage model of magma transport and degassing involves alternating periods of magma ascent and magma ponding. Initially, volatile-bearing magma ascends from depths of $9-15 \mathrm{~km}$, driven by buoyancy. During decompression, the magma loses gas, particularly $\mathrm{CO}_{2}$ and sulphur. The magma eventually ponds at its neutral buoyancy level. At this point, the gas-saturated magma cools and crystallizes, thereby liberating gas under isobaric conditions. As a result, $\mathrm{CO}_{2}$ is depleted from the magma whereas $\mathrm{H}_{2} \mathrm{O}$ and $\mathrm{SiO}_{2}$ are enriched. The $\mathrm{H}_{2} \mathrm{O}$ enrichment is caused by its increased solubility in the magma as $\mathrm{CO}_{2}$ is degassed, whereas $\mathrm{SiO}_{2}$ is enriched by fractional crystallization. The density of the magma decreases as the level of dissolved $\mathrm{H}_{2} \mathrm{O}$ increases, eventually causing the magma to become buoyant once more and to continue its ascent, either to erupt or to freeze at shallow depths.
\end{abstract}

Keywords: volcano, volatiles, degassing, magma transport.

The nature of the degassing process within a volcanic edifice is critically important to the nature of eruptions, whether explosive or effusive, from the volcano. Our understanding of how volcanoes degas has taken major steps forward in the past 20 years. Advances in remote sensing, petrology, and theoretical understanding, to name but a few fields, have broadened our knowledge of the mechanisms that control degassing.

Volatile solubilities, notably for water and carbon dioxide, are now known with some accuracy (Blank \& Brooker 1994; Holloway \& Blank 1994; McMillan 1994; Dixon \& Stolper 1995). Depth is a fundamental control on how much dissolved gas a magma can contain (Silver et al. 1990). Degassing can take place under closed-system or open-system conditions (Eichelberger et al. 1986), with important consequences for the amount of overpressure, which develops within the volcano (Fischer et al. 1994; Stix \& Layne 1996; Stix et al. 1997). As a result, some volcanoes can be considered leaky systems, whereas others appear to be sealed. An individual volcano also may alternate between leaky and sealed-type behaviour as a function of time.
As magma is transported from a deep reservoir to the surface, it may pass through several stages, which will affect its degassing behaviour. Gas-bearing magma initially ascends because of its buoyancy. During ascent, gas is lost as the magma decompresses and volatile solubilities decrease. The degassing style will lie somewhere in the continuum between open-system and closedsystem degassing. For example, bubbles formed during decompression may be retained in the magma as a result of its ascent velocity and its increasing viscosity as gas is lost. On the other hand, gas may be removed through sidewalls if the ascent velocity is comparatively slow (Jaupart 1998; Wilson 1998; Massol \& Jaupart 1999).

As it rises, the magma may reach a neutral buoyancy level at which it ponds at shallow levels within the crust. At this point, the magma will differentiate by cooling and crystallization. The magma also will continue to degas, but the style of degassing may change from that driven by decompression during ascent.

The amount of magma, and the nature of the reservoir system that stores the magma, also have important implications for 
degassing styles and mechanisms (Fink et al. 1992). Largevolume reservoirs will tend to lose less gas through sidewalls compared with small-volume systems wherein magma is stored in intricate conduit networks. In these small-volume systems, the surface area of magma in contact with the sidewalls is high, and gas is therefore lost more readily.

The parameters above ultimately bear upon the total amount of sulphur dioxide and other gases that a volcano releases to the atmosphere. Rose et al. (2000) have discussed the problems of highly variable excess sulphur release from subduction-related volcanoes and have shown that $\mathrm{SO}_{2}$ and ash are separated in eruption columns, with the $\mathrm{SO}_{2}$ accumulating at higher altitudes than the ash. This concentration and fractionation of $\mathrm{SO}_{2}$ in the atmosphere is controlled, in part, by: (1) the ascent rate of the magma; (2) the length of time it is able to pond at shallow depths; (3) the extent and dimensions of the reservoir in which ponding occurs; (4) whether the magmatic-hydrothermal system is sealed or leaky.

With these controls in mind, this paper examines magmatic volatile and light lithophile element contents in tephras erupted from Nevado del Ruiz volcano in 1985 and 1989. We have characterized the pre-eruptive element distributions in the magmas beneath the volcano by analysing melt inclusions trapped within plagioclase and pyroxene phenocrysts. Simultaneously, we characterized the magma that is partially degassed during the eruptions by analysing the matrix glasses adhering to the phenocrysts. The observed elemental variations are explained in terms of magma evolution during ascent and emplacement. We present a model of degassing at Nevado del Ruiz that has general application to other subduction-related volcanoes.

\section{Nevado del Ruiz volcano}

Nevado del Ruiz is located in the Cordillera Central of the Andes of Colombia, c. $140 \mathrm{~km}$ WNW of the capital, Bogotá (Fig. 1). Its geographical position is $4.90^{\circ} \mathrm{N}$ and $75.32^{\circ} \mathrm{W}$, and its summit elevation is $5321 \mathrm{~m}$. Nevado del Ruiz is one of the many volcanoes that are found in the Cordillera Central, and it marks the northernmost extent of a large high-altitude plateau, which also includes Nevado del Tolima (elevation $5200 \mathrm{~m}$ ) c. $30 \mathrm{~km}$ to the south. This plateau is called the Ruiz-Tolima complex.

Along with Puracé and Galeras volcanoes, Nevado del Ruiz is one of the most active volcanoes in Colombia. Its recent history of eruptions with Volcano Explosivity Index (VEI) values of three or greater includes events in 1595 and 1845 , both of which generated large destructive lahars from melting of the summit icecap.

The volcano began showing signs of reactivation in late 1984. The first felt seismicity occurred in November 1984, and increased fumarolic activity was noted in February 1985 (Williams 1987). Notable increases in the gas column were seen in June 1985, which may have corresponded to the arrival of new magma at shallow levels. A small eruption occurred on 11 September 1985 , preceded by an increase in seismicity on 5 September with banded tremor prominent from 4 to 11 September (Martinelli 1990). The eruption produced lithic ash, and a small avalanche in the Rio Azufrado valley, which flowed more than $27 \mathrm{~km}$. Although no solid juvenile material (i.e. pumice) was erupted, about $90000 \mathrm{t}$ of sulphur dioxide was released (Krueger et al. 1990), suggesting that the eruption was in fact magmatic and not phreatic. The principal eruption occurred on 13 November 1985 with no obvious precursors. Approximately $3.9 \times 10^{7} \mathrm{~m}^{3}$ of tephra were erupted (Naranjo et al. 1986), $660000 \mathrm{t}$ of $\mathrm{SO}_{2}$ were released (Krueger et al. 1990), and lahars were generated from melting of the icecap. The lahars flowed through the towns of

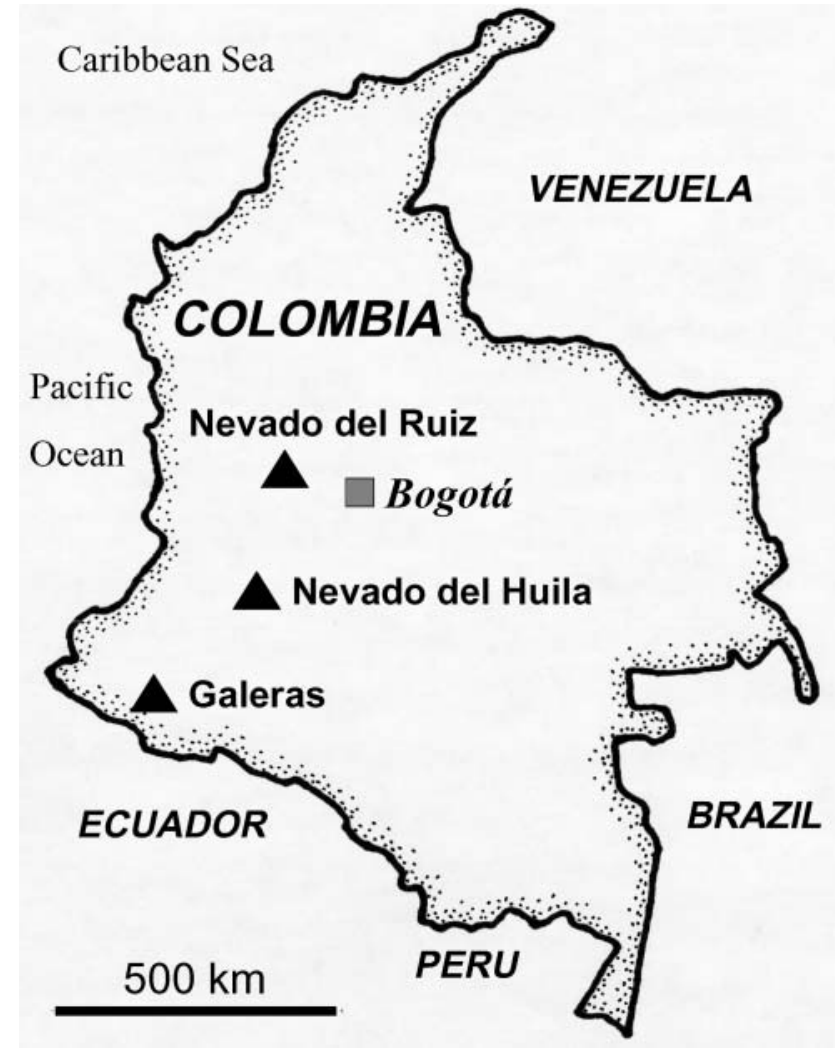

Fig. 1. Location map of Nevado del Ruiz volcano in Colombia.

Armero to the east and Chinchiná to the west, killing approximately 25000 people.

A high level of activity was maintained in the years following the 1985 eruptions. Another eruption, preceded by 3 months of heightened seismicity, occurred on 1 September 1989. A lahar again was generated in the Rio Azufrado valley and flowed to $3800 \mathrm{~m}$ elevation, destroying a bridge at $4000 \mathrm{~m}$. By the mid1990 s, the volcano had decreased its activity significantly.

The sustained activity of the volcano over nearly 10 years suggests that the magmatic-hydrothermal system is extensive and possibly related to an older buried caldera (Williams \& Meyer 1988).

\section{Methods}

\section{Sampling and petrography}

A representative suite of juvenile pumice samples was collected in 1989 from the 13 November 1985 and 1 September 1989 eruptions. From this suite, four pumice samples from the 1985 eruption (R0A, R0B, R0C, $\mathrm{R} 0 \mathrm{~F}$ ), and one pumice from the 1989 eruption (103b) were studied in detail. Major mineral phases include plagioclase and pyroxene, with small amounts of opaque minerals, olivine, apatite, and sometimes biotite.

The 1985 eruptive products include samples R0A and R0B, both of which are comparatively homogeneous, grey-brown, and highly vesiculated pumices. Major constituents include zoned plagioclase, orthopyroxene, and clinopyroxene. Sample R0F is a dark grey pumice that is comparatively dense, with few large vesicles, yet is uniformly microvesicular. This sample contains large plagioclase and pyroxene crystals, some of which have a sponge-like texture. The crystals have many melt inclusions. Biotite also is present; it is oxidized and altered with rims of opaque minerals, indicating that it is unstable and out of equilibrium. 
Sample R0C is a mingled pumice, with white material found as streaks and blebs in more mafic material. The boundaries between the two types of material are sharp, and hybridization is not clearly evident. The white material is partially vesiculated and crystal rich, with plagioclase and pyroxene clots.

The 1989 sample is 103b, a single large pumice fragment that is vesicular and has a glassy groundmass. Major phenocrysts include plagioclase, clinopyroxene, and orthopyroxene. Several small grains of amphibole were seen as inclusions in a plagioclase phenocryst, and one partial grain of resorbed amphibole also was noted.

\section{Sample preparation}

Plagioclase, pyroxene and glassy grains were hand-picked from crushed pieces of the pumices. Mineral grains and glassy fragments were mounted in epoxy in 1 inch diameter metal rings with chips of glass standards. The mounts then were polished to expose melt inclusions at the surface. The melt inclusions and matrix glasses were carefully documented using reflected and transmitted light microscopy. Melt inclusions selected for microbeam analysis were free from cracks and bubbles. Matrix glasses selected for analysis were generally adhered to mineral grains. All melt inclusions and matrix glasses chosen were completely glassy, i.e. they had not undergone any devitrification and did not contain microlites or microphenocrysts.

\section{Analytical methods}

Major elements, fluorine, chlorine, and sulphur were analysed by a Camebax electron microprobe at McGill University. Operating conditions were $15 \mathrm{kV}, 10-30 \mathrm{nA}$, and a $10-15 \mu \mathrm{m}$ defocused beam. For calibration, a series of glass standards was chosen that corresponded closely to the major element compositions of the melt inclusions and matrix glasses. To calibrate major elements, two peralkaline rhyolitic glasses were used (KN-9, KE-12). Fluorine was calibrated with KE-12 (4300 ppm F), chlorine with $\mathrm{KN}-9$ (3100 ppm Cl), and sulphur with NBS-620 (1120 ppm S). Detection limits were $100-150 \mathrm{ppm}$ for $\mathrm{Cl}, 100-200 \mathrm{ppm}$ for $\mathrm{S}$, and c. $500 \mathrm{ppm}$ for $\mathrm{F}$. To minimize volatilization effects (e.g. loss of sodium) in the samples as a result of the electron beam, the various elements were analysed in the same order and for the same length of time for both standards and unknowns. Accuracy was checked periodically by analysing the standards as unknowns, and sodium loss was monitored carefully and accounted for.

Secondary ionization mass spectrometry (SIMS) analyses were made using the Cameca IMS $3 \mathrm{f}$ ion microprobe at Woods Hole Oceanographic Institution. The sample was bombarded with primary $\mathrm{O}^{-}$ions, which were accelerated through a nominal potential of $8.15 \mathrm{kV}$. This primary beam was focused into a spot diameter of 15-30 $\mu \mathrm{m}$. Sputtered secondary ions were energy filtered with a sample offset of $-30 \mathrm{~V}$ $\left(-50 \mathrm{~V}\right.$ for $\left.{ }^{1} \mathrm{H}^{+}\right)$and an energy window of $\pm 10 \mathrm{~V}$, to effectively eliminate isobaric interferences. Coupled with the energy filtering, the modest intrinsic mass resolving power of the instrument in this mode (c. 300 ) is generally sufficient to effectively eliminate the potential interference of ${ }^{27} \mathrm{Al}^{3+}$ on ${ }^{9} \mathrm{Be}^{+}$. Analyses involved repeated cycles of peak counting, first on ${ }^{1} \mathrm{H}^{+}$and ${ }^{30} \mathrm{Si}^{+}$and then on ${ }^{7} \mathrm{Li}^{+},{ }^{9} \mathrm{Be}^{+},{ }^{11} \mathrm{~B}^{+},{ }^{19} \mathrm{~F}^{+}$, and ${ }^{30} \mathrm{Si}^{+}$, with a background position measured to monitor the noise level of the electron multiplier detector. Measured ratios were reduced to elemental concentrations using well-characterized felsic glasses as standards $\left(\mathrm{H}_{2} \mathrm{O}\right.$ : PCD 0.18 wt.\%, IF35-1 1.25 wt.\%, M3N 3.5 wt.\%, M6N 6.1 wt.\%; Li, Be, B: UTR-2 with $63.4 \mathrm{ppm}, 8.7 \mathrm{ppm}$, and $17.7 \mathrm{ppm}$, respectively). The chemical analyses are tabulated in Table 1.

\section{Results}

\section{Major element abundances and trends}

In general, the melt inclusions and matrix glasses are evolved, silica-rich materials, implying that the Ruiz magmas underwent extensive high-level differentiation by fractional crystallization before they were erupted in 1985 and 1989.
All melt inclusions have anhydrous-normalized silica contents $>70$ wt.\%. By contrast, several matrix glasses have $\mathrm{SiO}_{2}$ contents as low as 65 wt.\%. In a plot of $\mathrm{SiO}_{2}$ v. $\mathrm{MgO}$ (Fig. 2a), there are two subparallel evolutionary trends, one of which is more evolved than the other. These broad trends are suggestive of two distinct magmas. The presence of two magmas, and their macroscopic mixing, is supported by the pumice textures, some of which exhibit mingling features. Previous work also has documented the presence of two distinct magma compositions beneath Nevado del Ruiz, one andesitic and the other dacitic, with mixing and mingling between the two during the November 1985 eruption (Gourgaud \& Thouret 1990; Melson et al. 1990; Sigurdsson et al. 1990).

In detail, the $\mathrm{SiO}_{2}-\mathrm{MgO}$ plot reveals some interesting relationships. For the R0A and R0B samples, the pyroxene melt inclusions define part of the upper evolutionary trend, whereas the plagioclase melt inclusions plot on the lower, more evolved trend, and at lower silica contents. The matrix glasses tend to be more mafic and appear to follow the lower trend. For R0F, the plagioclase melt inclusions cluster mostly along the lower trend, with the lowest-silica samples showing excursions toward the upper trend. The R0F pyroxene melt inclusions and matrix glasses plot closer to the upper trend and at intermediate points above the plagioclase melt inclusions. For R0F, therefore, most glasses are part of the lower trend, with some excursions to higher $\mathrm{MgO}$ levels. The R0C samples also fall principally within the lower trend. These glasses tend to be the most evolved of all the samples. Interestingly, the R0C pyroxene melt inclusions are more evolved than plagioclase melt inclusions, whereas the matrix glasses overlap both.

For sample 103b from the 1989 eruption, the plagioclase melt inclusions plot along the lower trend, and are comparatively evolved. The pyroxene melt inclusions, on the other hand, tend to be more closely associated with the upper trend. These relations between plagioclase and pyroxene melt inclusions are similar to those for R0A, R0B and R0F, but not R0C. The matrix glasses for sample $103 \mathrm{~b}$ have variable compositions, ranging from c. 67 to $75 \mathrm{wt} . \% \mathrm{SiO}_{2}$.

These same evolutionary trends are observed in other variation diagrams. In a $\mathrm{SiO}_{2}$ v. $\mathrm{Fe}_{2} \mathrm{O}_{3}{ }^{*} / \mathrm{K}_{2} \mathrm{O}$ plot (Fig. 2b), the trends are consistent with the $\mathrm{SiO}_{2}-\mathrm{MgO}$ diagram. For example, the $\mathrm{R} 0 \mathrm{~F}$ pyroxene melt inclusions mostly plot on the upper trend, whereas the R0F matrix glasses fall on both trends, as well as between. The 103b pyroxene melt inclusions form part of the upper trend but are displaced to slightly lower $\mathrm{SiO}_{2}$ and $\mathrm{Fe}_{2} \mathrm{O}_{3}{ }^{*} / \mathrm{K}_{2} \mathrm{O}$ relative to the R0A and R0B pyroxene melt inclusions.

In summary, there appear to be two principal evolutionary trends, with the more evolved (lower $\mathrm{MgO}, \mathrm{Fe}_{2} \mathrm{O}_{3}$ ) being the principal trend. Samples that fall between the two trends, as exemplified by the R0F and $103 \mathrm{~b}$ pyroxene melt inclusions, could indicate a magma mixing relationship. The most evolved samples are the R0C pyroxene melt inclusions and matrix glasses, and the most primitive samples are the R0A and R0B matrix glasses.

\section{Water contents}

The water contents in the Ruiz melt inclusions are low compared with more silicic magmas, which generally have water contents of 4-6 wt.\% (Dunbar \& Hervig 1992a, b; Stix \& Layne 1996; Wallace et al. 1999). These lower values are suggestive of magmas that resided at shallow depths for a period of time, and this is consistent with the evolved nature of the glasses. Independent evidence indicates that the magmas also resided at deeper levels $(9-15 \mathrm{~km})$ before the 1985 eruptions (Williams \& 


\begin{tabular}{|c|c|c|c|}
\hline 嵒 & 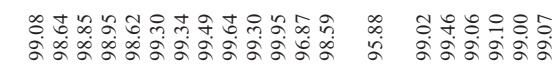 & 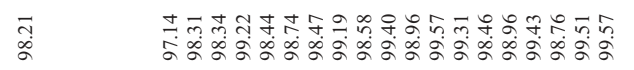 & 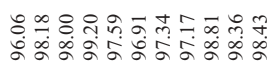 \\
\hline$\tau$ & 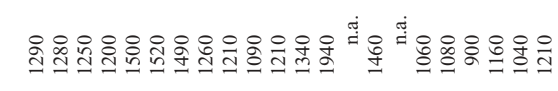 & 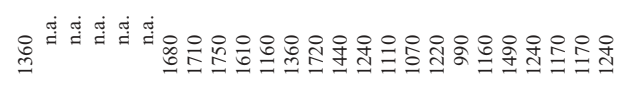 & 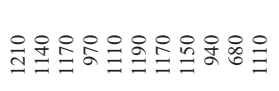 \\
\hline is & 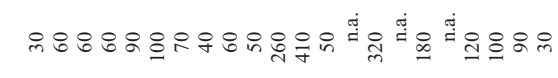 & 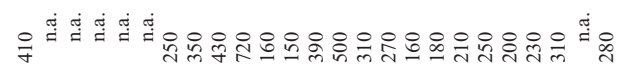 & 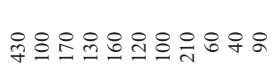 \\
\hline w & \& & 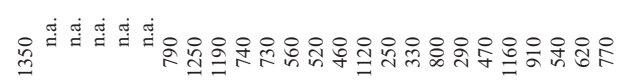 & 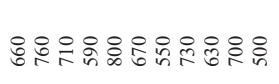 \\
\hline$\infty$ & 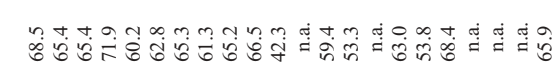 & 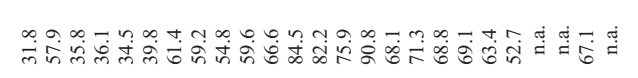 & 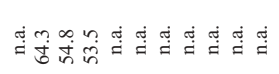 \\
\hline 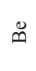 & 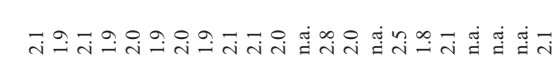 & 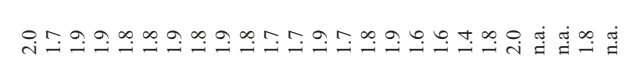 & 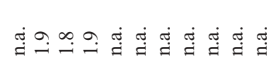 \\
\hline$\overline{7}$ & 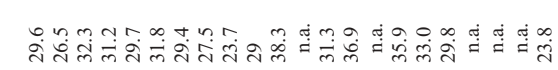 & 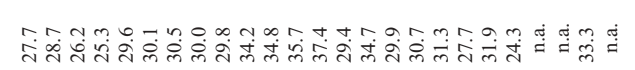 & 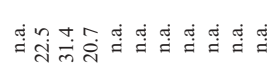 \\
\hline 茎 & 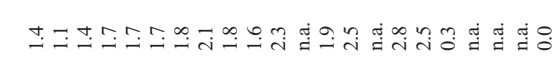 & & 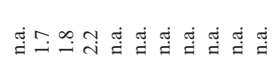 \\
\hline$\stackrel{\circ}{\circ}$ & 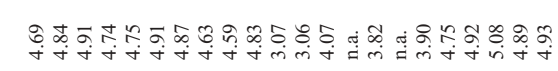 & 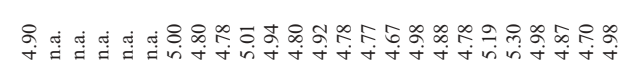 & 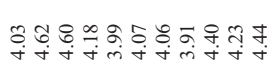 \\
\hline $\begin{array}{l}\circ \\
\tilde{\tilde{z}}\end{array}$ & 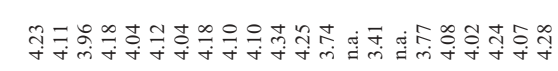 & 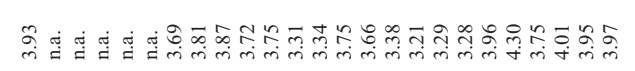 & 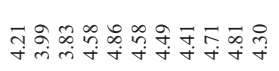 \\
\hline ¿ & 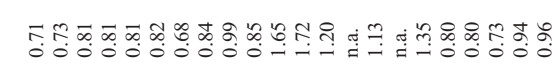 & 局苯 & 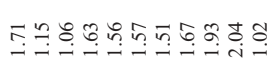 \\
\hline$\frac{8}{2}$ & 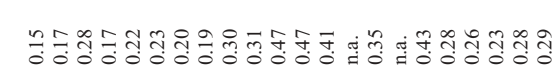 & 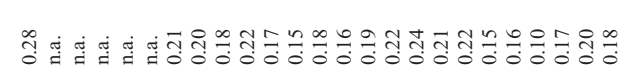 & 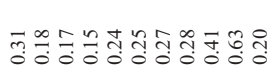 \\
\hline$\stackrel{\circ}{2}$ & 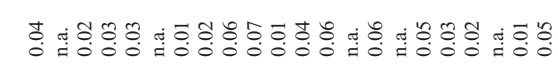 & 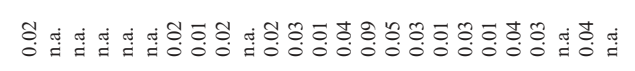 & 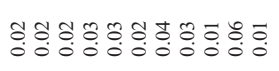 \\
\hline 每 & 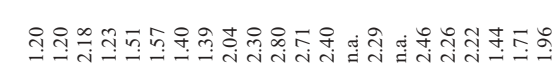 & 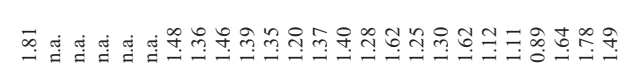 & 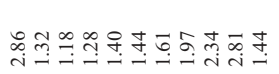 \\
\hline 怘 & 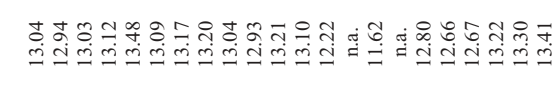 & 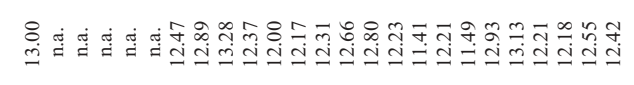 & 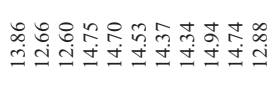 \\
\hline$\overbrace{\mathscr{F}}$ & 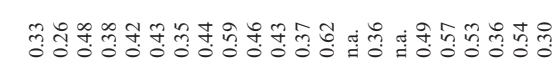 & 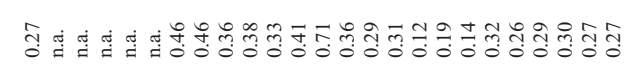 & 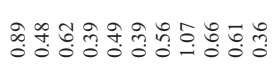 \\
\hline$\frac{\delta}{2}$ & 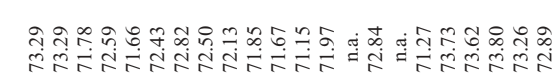 & 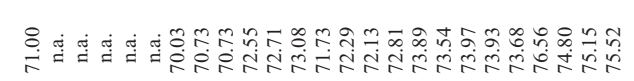 & 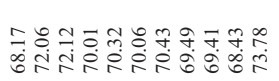 \\
\hline & 告 & 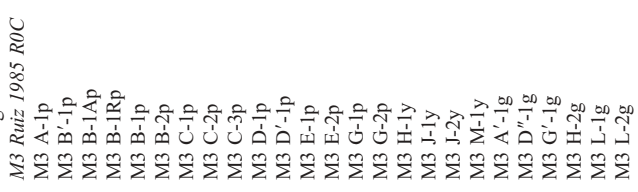 & 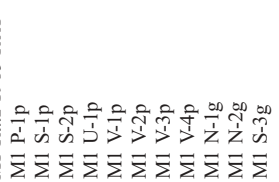 \\
\hline
\end{tabular}




\begin{tabular}{|c|c|c|c|}
\hline 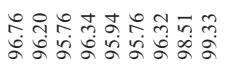 & 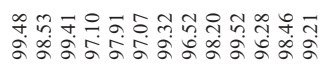 & 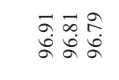 & 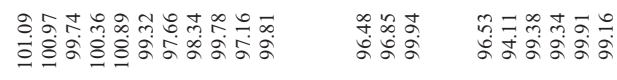 \\
\hline 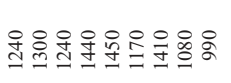 & 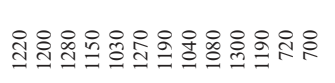 & 윾 号号栗 & 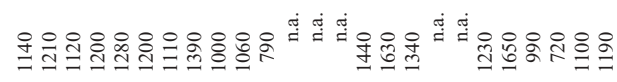 \\
\hline 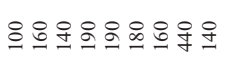 & 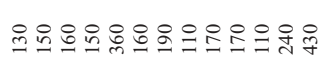 & ํㅠㅁㅛㅛㅇㅝ & 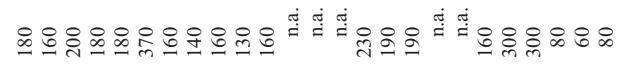 \\
\hline 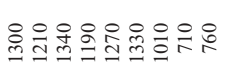 & 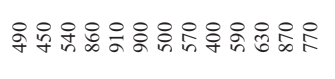 & 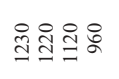 & 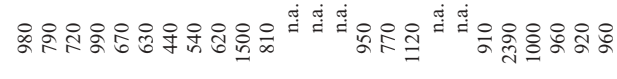 \\
\hline 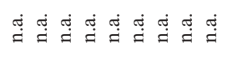 & 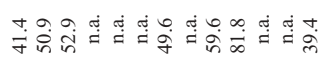 & 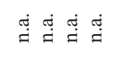 & 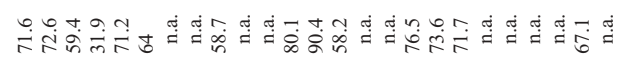 \\
\hline 鸟 异 & 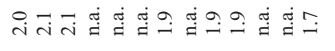 & 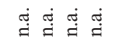 & $\overrightarrow{\mathrm{N}} \sim Q \mathcal{Z}=9$ S \\
\hline 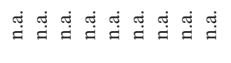 & 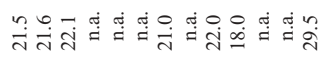 & 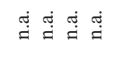 & 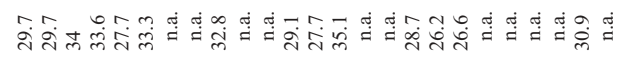 \\
\hline 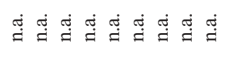 & 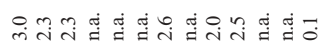 & 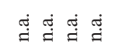 & 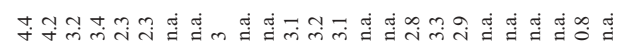 \\
\hline 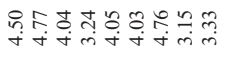 & 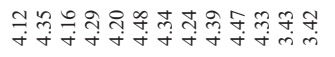 & 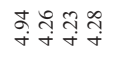 & 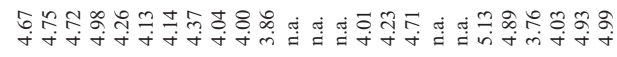 \\
\hline 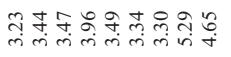 & 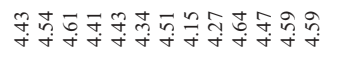 & 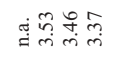 & 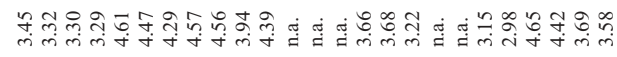 \\
\hline 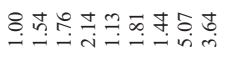 & 업 & 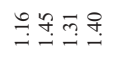 & 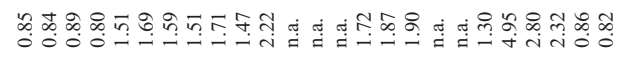 \\
\hline 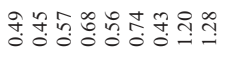 & 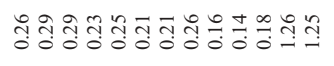 & 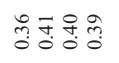 & 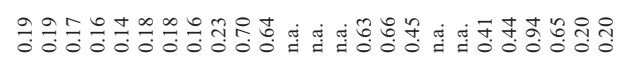 \\
\hline 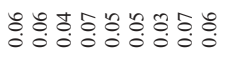 & 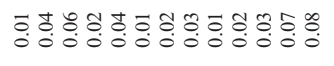 & 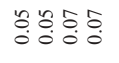 & 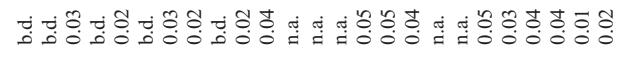 \\
\hline 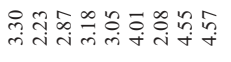 & 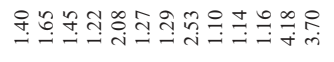 & 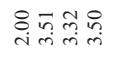 & 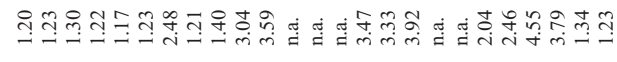 \\
\hline 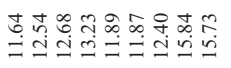 & 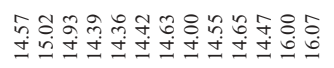 & 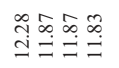 & 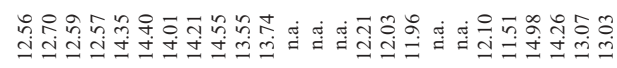 \\
\hline 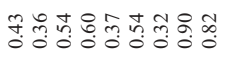 & 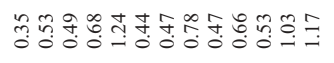 & 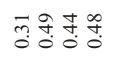 & 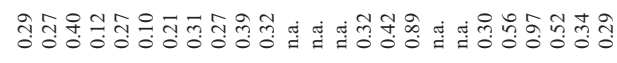 \\
\hline 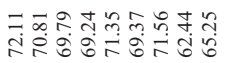 & 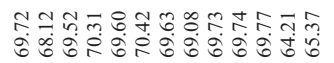 & 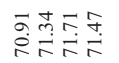 & 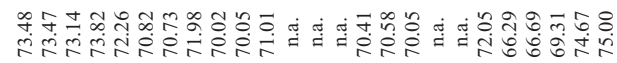 \\
\hline & $\theta$ & 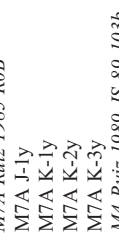 & 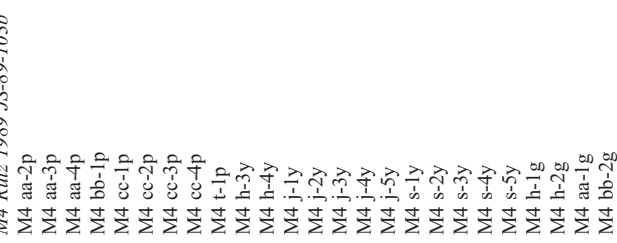 \\
\hline
\end{tabular}



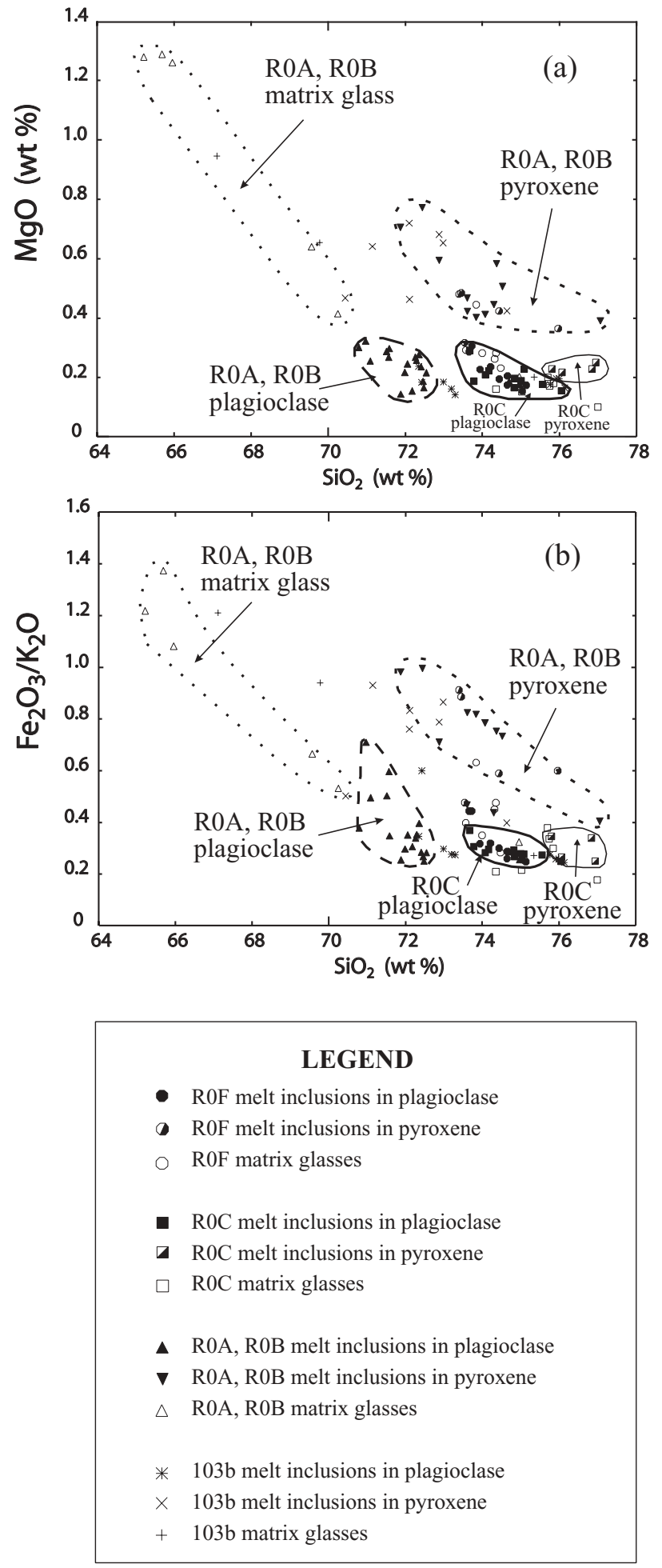

Fig. 2. (a) $\mathrm{Plot}$ of $\mathrm{MgO}$ v. $\mathrm{SiO}_{2}$ for melt inclusions and matrix glasses from Nevado del Ruiz. (b) Plot of $\mathrm{Fe}_{2} \mathrm{O}_{3}{ }^{*} / \mathrm{K}_{2} \mathrm{O}$ v. $\mathrm{SiO}_{2}$.

Meyer 1988). These two lines of evidence together imply that magma moved to shallow levels before the eruptions and lost $\mathrm{H}_{2} \mathrm{O}$ by decompressive degassing, before crystallization and entrapment of melt inclusions.

Of the 1985 samples, the R0F plagioclase melt inclusions have the lowest $\mathrm{H}_{2} \mathrm{O}$ contents $(1.6 \pm 0.3$ wt.\%), whereas R0F pyroxene melt inclusions have somewhat higher contents $(2.2 \pm 0.5$ wt.\%) (Fig. 3a). The R0A and R0B plagioclase melt inclusions have intermediate values $(2.3 \pm 0.4 \%)$, whereas the R0C pyroxene melt inclusions have the highest water contents $(3.1 \pm 0.2$ wt.\%). Although R0A-R0B and R0C plagioclase melt inclusions have different silica contents, their average water contents are the same $(2.3 \pm 0.4 \%)$.

Compared with the 1985 samples, the 1989 melt inclusions have higher water contents (Fig. 3b). Plagioclase melt inclusions have an average of $3.3 \pm 0.8$ wt. $\% \mathrm{H}_{2} \mathrm{O}$, whereas pyroxene melt inclusions have only slightly less $(3.1 \pm 0.2 \mathrm{wt} . \%)$.

For all samples, the matrix glasses have significantly lower water. Most matrix glasses contain $<0.5 \mathrm{wt} . \% \mathrm{H}_{2} \mathrm{O}$, indicative of syneruptive degassing, although there are several samples that appear to have retained more water (Table 1). In summary, the melt inclusion data indicate pre-eruptive water contents varying from 1.6 to 3.3 wt.\%. These direct SIMS measurements are consistent with previous indirect estimates by Melson et al. (1990) (1-4 wt.\% $\mathrm{H}_{2} \mathrm{O}$ ) and Sigurdsson et al. (1990) (3-4 wt.\% $\mathrm{H}_{2} \mathrm{O}$ ).

\section{Halogen and sulphur contents}

Fluorine. Compared with the other elements analysed, fluorine has the greatest analytical uncertainty, for both SIMS and electron microprobe analyses. The electron microprobe data are discussed here, as they are more comprehensive.

For R0A and R0B, pyroxene melt inclusions have higher fluorine contents than do plagioclase melt inclusions (an average of $1200 \pm 120 \mathrm{ppm}$ v. $650 \pm 150 \mathrm{ppm}$ ) (Fig. 4a). For R0F, pyroxene melt inclusions have similar fluorine $(1010 \pm 180 \mathrm{ppm})$ to plagioclase melt inclusions $(910 \pm 110 \mathrm{ppm})$. For R0C, plagioclase melt inclusions exhibit a large range of fluorine values $(870 \pm 330 \mathrm{ppm})$, whereas the evolved pyroxene melt inclusions have low fluorine $(420 \pm 260 \mathrm{ppm})$. For sample $103 \mathrm{~b}$ from the 1989 eruption, the trends are similar to those for R0A and R0B discussed above, with pyroxene melt inclusions enriched in fluorine compared with the plagioclase melt inclusions $(1210 \pm$ 580 ppm v. $710 \pm 190$ ppm).

In summary, the trends closely mimic those of the major elements. This is consistent with fluorine being a conserved, incompatible element that prefers to partition in favour of the melt relative to a fluid or volatile phase (Webster 1990). This conservative nature of fluorine also is exhibited by the matrix glasses, which have fluorine levels similar to those of the melt inclusions.

Chlorine. The chlorine trends are clearly different from those of fluorine (Fig. 4b). For example, the R0A and R0B melt inclusions in plagioclase and pyroxene are rather similar, not distinct as for fluorine and major elements. For R0F, the pyroxene melt inclusions have $\mathrm{Cl}$ values both higher and lower than the plagioclase melt inclusions, and there is significant overlap between the two (average $1410 \pm 330 \mathrm{ppm}$ for pyroxene inclusions v. $1330 \pm 130 \mathrm{ppm}$ for plagioclase inclusions). For $\mathrm{R} 0 \mathrm{C}$, plagioclase melt inclusions are enriched in chlorine ( $1500 \pm 220 \mathrm{ppm}$ on average) relative to the evolved pyroxene melt inclusions (1100 $\pm 100 \mathrm{ppm}$ on average). Sample 103b from the 1989 eruption is similar to R0F; the pyroxene melt inclusions have a wider range with both higher and lower values (average $1310 \pm 310 \mathrm{ppm}$ ) than the plagioclase melt inclusions (average $1180 \pm 110 \mathrm{ppm}$ ). Lastly, the matrix glasses generally have the lowest values observed, with concentrations $<1300 \mathrm{ppm}$. Most matrix glasses contain $<1000 \mathrm{ppm} \mathrm{Cl}$. 
(a)

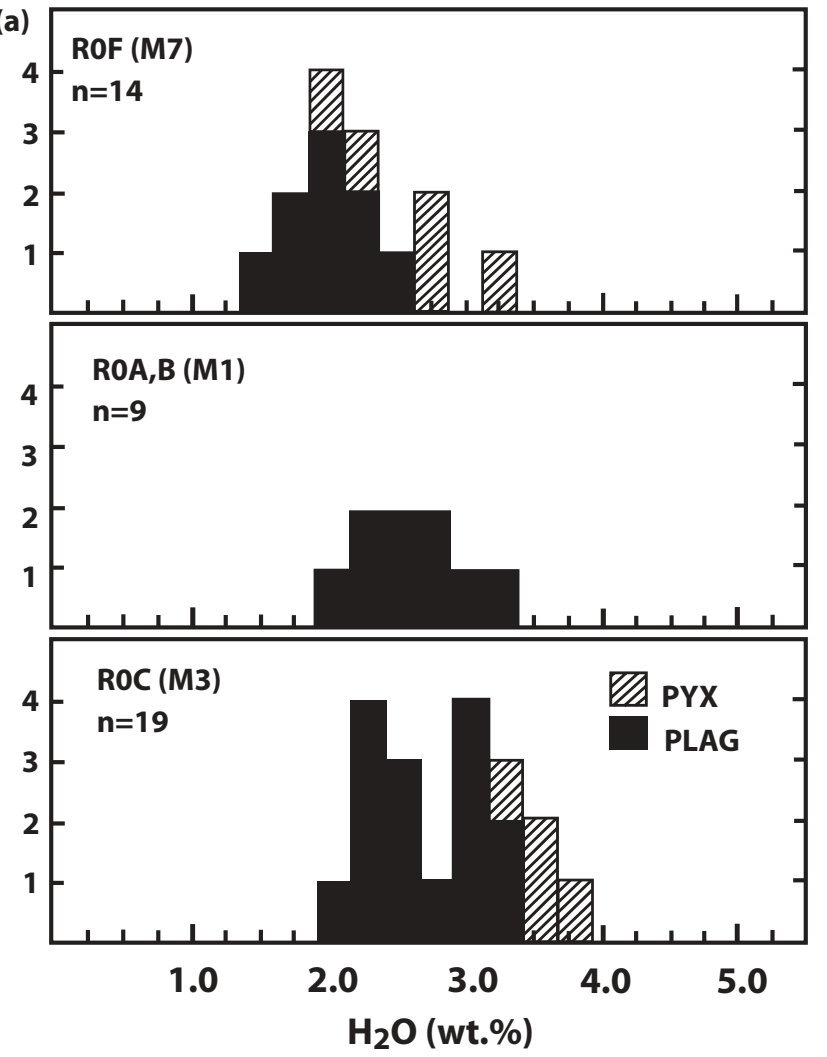

(b)

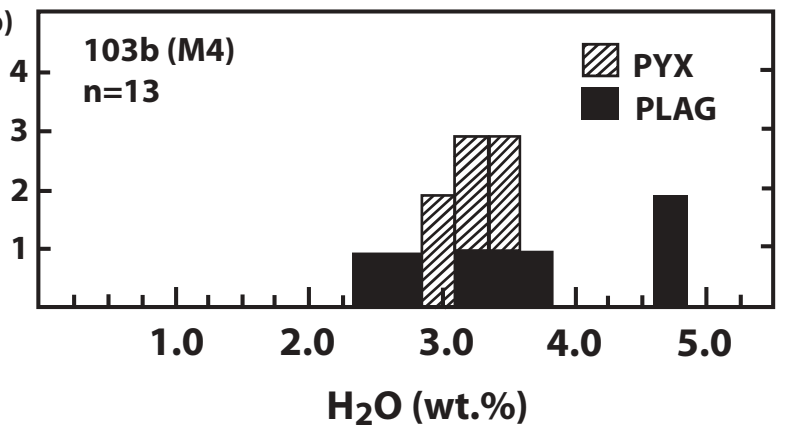

Fig. 3. (a) Water contents in weight percent of melt inclusions from four pumices (R0A, R0B, R0C, R0F) erupted by the 13 November 1985 eruption. (b) Water contents of melt inclusions in one pumice (103b) from the 1 September 1989 eruption.

It is well established that $\mathrm{Cl}$ can be lost from magma by degassing processes, because, in contrast to fluorine, it partitions in favour of the volatile phase relative to the magma (Webster $1992 a, b)$. The two trends defined by the major elements and fluorine cannot clearly be seen for $\mathrm{Cl}$; in detail, melt inclusions for samples R0A-R0B, R0F, and $103 \mathrm{~b}$ tend to group together. This clustering may indicate that samples from the upper trend have lost greater amounts of $\mathrm{Cl}$ and are therefore more degassed. The comparatively low $\mathrm{Cl}$ contents in the $\mathrm{R} 0 \mathrm{C}$ pyroxene melt inclusions also imply that these samples have lost $\mathrm{Cl}$, despite their evolved, water-rich nature.

Sulphur. Because of the generally low values of sulphur in the glasses, the analytical precision by electron microprobe is poorer than for the other elements. Nevertheless, some important
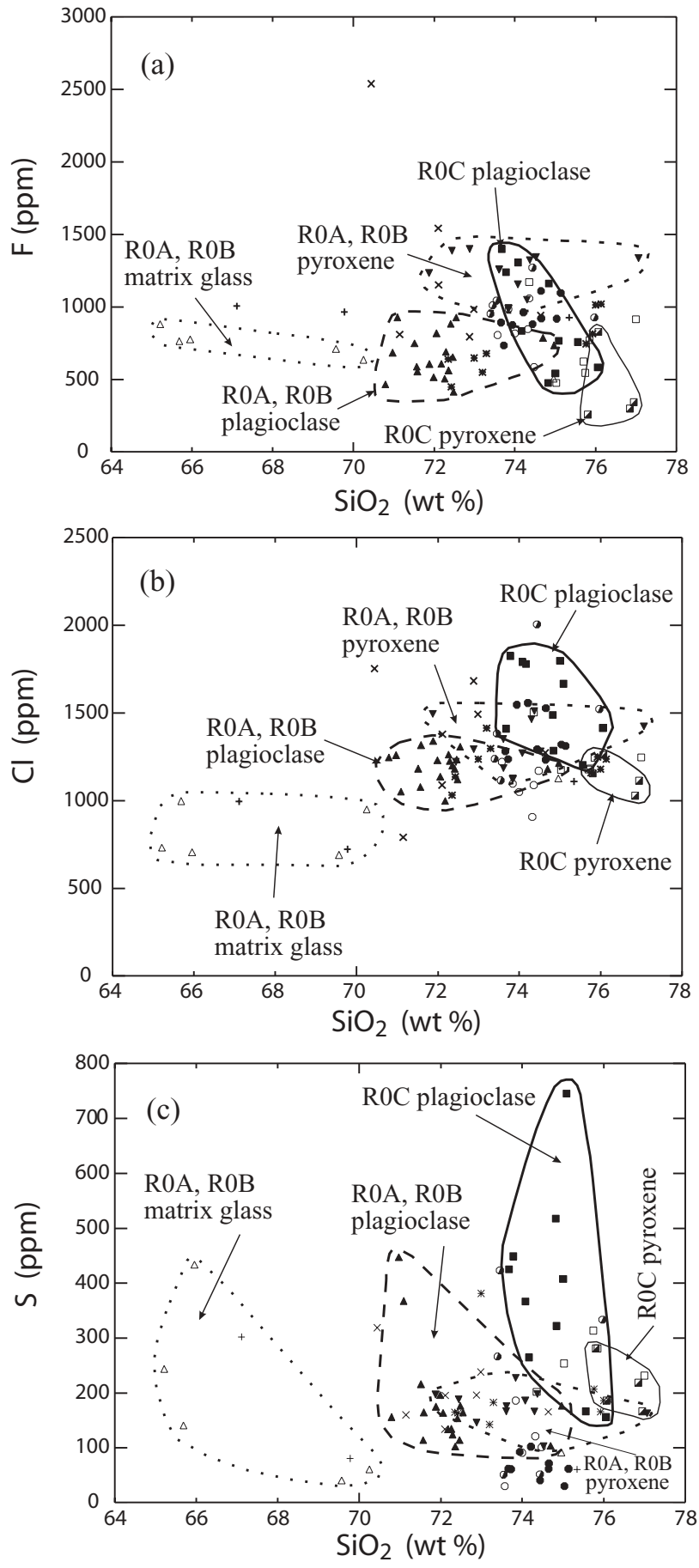

Fig. 4. Halogen and sulphur concentrations (in ppm) of melt inclusions and matrix glasses. (a) Fluorine; (b) chlorine; (c) sulphur.

relationships can be established. As for $\mathrm{Cl}$, sulphur contents are similar among the various melt inclusions in R0A and R0B (Fig. 4c). For R0F, the pyroxene melt inclusions show extremely variable sulphur values (average $220 \pm 160 \mathrm{ppm}$ ), overlapping at low concentrations with the plagioclase melt inclusions, which are depleted in sulphur (average $60 \pm 20 \mathrm{ppm}$ ). R0C samples are similar, but here the plagioclase melt inclusions exhibit considerable variability (average $370 \pm 170 \mathrm{ppm}$ ), whereas the evolved pyroxene melt inclusions are both more clustered and more 
depleted in sulphur (average $210 \pm 50 \mathrm{ppm}$ ). The 103b melt inclusions in plagioclase and pyroxene have comparable sulphur contents, as seen for R0A and R0B. Finally, the matrix glasses are only slightly lower in sulphur relative to the melt inclusions.

In summary, the sulphur data do not define two trends as do the major elements and fluorine. In fact, the sulphur data tend to homogenize the two groups, as do the $\mathrm{Cl}$ data. Another important point is that all sulphur concentrations are comparatively low; almost all samples contain $<500 \mathrm{ppm} \mathrm{S}$, and a great many contain $<200 \mathrm{ppm}$. Taken together, the $\mathrm{Cl}$ and $\mathrm{S}$ data imply substantial loss of these elements through pre-eruptive degassing.

\section{Boron, lithium, and beryllium contents}

Most glasses have lithium concentrations between 30 and 40 ppm (Fig. 5a). Plagioclase melt inclusions from sample R0F have perceptibly lower lithium contents, averaging $29 \pm 3 \mathrm{ppm}$ Li. Plagioclase melt inclusions from samples R0A and R0B have distinctly lower $\mathrm{Li}$ values $(22 \pm 4 \mathrm{ppm})$. Most glasses contain 1.4-2.4 ppm Be (Fig. 5b), and there is a perceptible depletion in Be with increasing silica contents.

Boron exhibits an extremely large range of concentrations, from c. $30 \mathrm{ppm}$ to nearly $100 \mathrm{ppm}$ (Fig. 5c). Plagioclase melt inclusions from samples R0A, R0B and R0C are highly variable, whereas the other samples have concentrations between 60 and
$80 \mathrm{ppm}$. The dramatic variability of boron remains clearly apparent when ratioed to Be (Fig. 5d).

In summary, variability with increasing $\mathrm{SiO}_{2}$ increases in the order $\mathrm{Be}, \mathrm{Li}, \mathrm{B}$. None of these three elements gives the appearance of being controlled by a simple process of fractional crystallization.

\section{Differences between melt inclusions and matrix glasses}

In all samples, $\mathrm{H}_{2} \mathrm{O}$ contents are lower in matrix glasses than in melt inclusions. This is an expected consequence of syneruptive release of water during eruption. In contrast, the other elements studied show much smaller, or even negligible, differences between melt inclusions and matrix glasses, even though there is significant variability within the various individual samples. For example, fluorine is basically identical between matrix glass and inclusions, whereas chlorine is slightly lower for matrix glasses, although there is overlap. The only sample that shows significant differences for chlorine is R0B. Likewise for sulphur, there are no clear differences between melt inclusions and matrix glasses, although there is comparatively large analytical uncertainty. The light lithophile elements ( $\mathrm{Li}, \mathrm{Be}$, and $\mathrm{B}$ ) also do not exhibit significant differences between melt inclusions and matrix glasses, although again there is a fairly high degree of variability
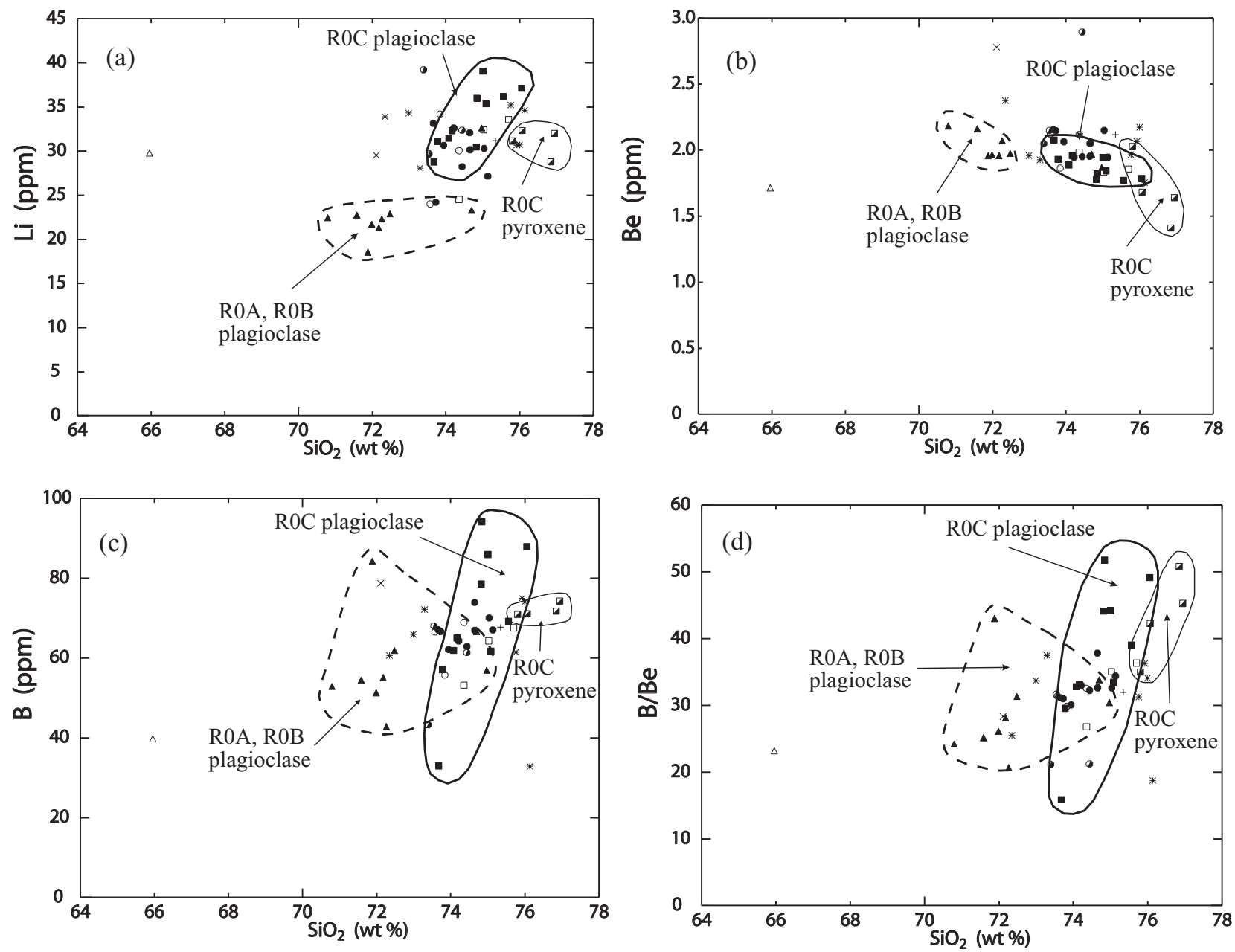

Fig. 5. Light lithophile element concentrations (in ppm) of melt inclusions and matrix glasses. (a) Lithium; (b) beryllium; (c) boron; (d) plot of B/Be. 
among the samples. In summary, the only element that shows a distinct and systematic difference is water.

As a final point, for several individual crystals it was possible to analyse a series of melt inclusions. In certain cases, the different inclusions have variable concentrations of elements. As an example, one pyroxene crystal from sample 103b (M4, crystal $\mathrm{j}$; see Table 1) contains three melt inclusions with boron contents of 58, 80, and $90 \mathrm{ppm}$. This small-scale heterogeneity is superimposed on the larger-scale variability among the different groups of melt inclusions and matrix glasses.

\section{Discussion}

Any model of volatile and light lithophile element behaviour at Nevado del Ruiz needs to address the following observations: (1) the large variability of element concentrations in the melt inclusions and matrix glasses; (2) the comparatively low $\mathrm{H}_{2} \mathrm{O}$ contents relative to other intermediate to felsic magmas; (3) the evolved nature of the glasses, particularly melt inclusions within pyroxenes from sample R0C and plagioclases from sample 103b; (4) the extremely large variability of $\mathrm{F}, \mathrm{Cl}, \mathrm{S}$, and $\mathrm{B}$ in melt inclusions within plagioclases from sample R0C; (5) the high concentrations and large variability of boron in the various glasses.

The following discussion assesses the depths at which the Nevado del Ruiz magmas evolved, proposes a model of degassing from the volcano, presents quantitative modelling of density and viscosity variations of the magma related to degassing, and discusses the problem of boron at Nevado del Ruiz and other subduction zone volcanoes.

\section{High-level magmatic processes at Nevado del Ruiz}

The andesitic tephras that were erupted from Nevado del Ruiz in 1985 and 1989 were probably derived from more mafic melts in the crust and mantle wedge above the subducting Nazca plate. In an early summary discussion of the Nevado del Ruiz magmatic system, a consensus view held that magmas ponded between 9 and $15 \mathrm{~km}$ before the 1985 eruptions, based on petrological and geophysical data (Williams \& Meyer 1988). This view was based on three observations. First, local deformation of the volcano was negligible both before and after the 13 November 1985 eruption (Banks et al. 1990). Second, seismicity was rarely ever observed below $7 \mathrm{~km}$ depth (Nieto et al. 1990). Third, calculations of the conduit length needed to erupt the volume of lithic ash observed were consistent with these depths (Williams \& Meyer 1988). Yet little material from these deep levels was erupted in the 1985 and 1989 events. Instead, the pumice that was erupted is evolved, consisting of rhyolitic glass and phenocrysts of plagioclase and pyroxene. Very little hornblende was seen, nor was mafic material observed. Thus, the juvenile products appear to be derived from higher levels in the crust, recording conditions in a shallower reservoir, or reservoirs, before the eruptions.

Several lines of evidence indicate that magmas beneath Nevado del Ruiz have experienced a complex history of ascent and ponding during their passage through the crust. By contrast with volcanoes such as Mount St. Helens and Mount Pinatubo, where magmas have ascended rapidly to produce major explosive eruptions, the magmas of Nevado del Ruiz appear to have been transported upward in a rather sluggish fashion. This fitful movement has allowed the magmas to stall at times and to lose (and gain) gas in a number of ways.

A central observation is that the melt inclusions from these eruptions have volatile element concentrations that are variable, both between and within phenocrysts. This variability indicates that crystals have trapped melt at various depths beneath the volcano. In some cases, the melt inclusions are vesicular, though no obvious connection, neck or breach exists between inclusion and crystal edge (Fig. 6). This feature strongly implies that they were trapped from an actively effervescing (gas exsolving) melt.

These observations are suggestive of a magma that ascended and degassed, trapping melt inclusions at a variety of depths. The simplest model for this is to transport the magma through a system of dykes, which allows degassing to occur for a wide range of depths and pressures. The two geochemical trends shown in Figure 2 reflect the presence and mingling of two magmas within this plexus of dykes. The more evolved lower trend, as exemplified by the plagioclase melt inclusions, may represent magma that evolved and differentiated at different levels in the conduit system. The less evolved upper trend, shown
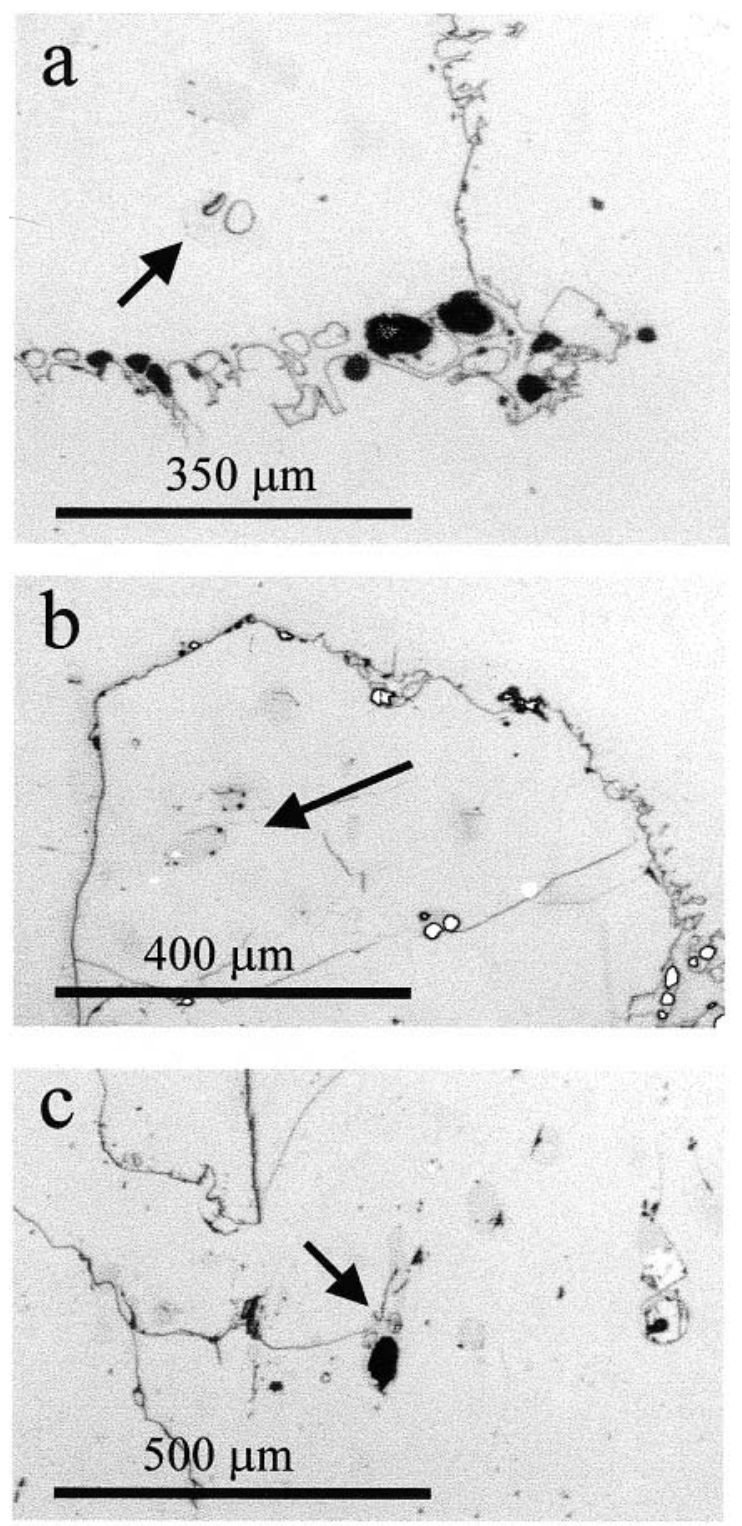

Fig. 6. Vesiculated melt inclusions in plagioclase crystals from sample 103b. Arrows point to melt inclusions. (a) Two bubbles forming in a melt inclusion. (b) Very small bubbles, as shown by the black dots, in two melt inclusions. (c) Two bubbles in a melt inclusion connected by a crack to the outside of the crystal. 
by the bulk of the pyroxene melt inclusions, represents a second magma that was subsequently introduced into the same conduit system and interacted with the first magma. This interaction caused mixing of phenocrysts from the two magmas and their simultaneous expulsion in a hybrid magma during eruption.

Further, all the glass compositions are highly evolved (Table 1). The great majority have silica contents higher than $70 \mathrm{wt} . \%$ on an anhydrous basis, and some glasses contain up to $77 \mathrm{wt} . \%$ $\mathrm{SiO}_{2}$. The rhyolitic compositions imply that the magma underwent significant amounts of crystallization and differentiation within a holding reservoir or reservoirs beneath the volcano (Sigurdsson et al. 1990; Vatin-Pérignon et al. 1990). These reservoirs are likely to be of small volume, considering the comparatively small amounts of magma that are erupted from this volcano during any single period of unrest. The reservoirs may be vertically extensive, such as widened dykes, allowing degassing to occur over a range of depths and pressures. Alternatively, they may be horizontally extensive, such as thin sills, which are able to distribute magma laterally within a zone of high permeability.

Sulphur contents in the melt inclusions are also low. Most are $<500 \mathrm{ppm}$, and some are $<100 \mathrm{ppm}$ (i.e. melt inclusions in plagioclases from R0F). In some cases, melt inclusions have lower sulphur values than certain matrix glasses from the same eruption. This observation implies that the melt inclusions represent magma that was trapped at a shallower depth than that erupted to form some portion of the matrix glasses. The low and highly variable sulphur values of the melt inclusions imply that the corresponding magmas lost significant amounts of sulphur, probably during ascent and storage in shallow reservoirs. This point is consistent with the huge $\mathrm{SO}_{2}$ output of Nevado del Ruiz during and following the 1985 eruptions (Krueger et al. 1990; Williams et al. 1990). A simple model of sulphur degassing therefore consists of (1) gas accumulation beneath an impermeable cap during times of repose (Williams \& Meyer 1988; Giggenbach et al. 1990), and (2) periodic release of this gas when the cap ruptures, as happened during the 1985 eruptions. The continued vigorous release of $\mathrm{SO}_{2}$ after the eruptions suggests that the cap only gradually resealed, over a period of years.

Our data consistently indicate that the magmas accumulated and ponded at shallow levels beneath the volcano. This important characteristic was first pointed out by Schaefer (1995). Indeed, the 10 years of restlessness exhibited by Nevado del Ruiz between 1985 and 1995 are strongly suggestive of a restless magma with significant energy, as shown by the high levels of seismicity and gas release during this time. The shallow nature of the magmas is supported by three lines of petrological evidence. First, the high silica contents of the glasses argue for low-pressure crystallization, as the solubility of silica increases as pressure decreases (Blundy \& Cashman 2001). Second, the mineral assemblage in the pumices is predominantly plagioclase and pyroxene, and hydrous phases such as amphibole or biotite are rarely observed. Third, the water contents measured in the melt inclusions are comparatively low compared with other magmas of similar and more silicic composition. Average values range from a minimum of $1.6 \mathrm{wt} . \%$ to a maximum of $3.3 \mathrm{wt} . \%$, with most melt inclusions falling between 2 and $3 \mathrm{wt} . \%$. Using these values, it is possible to calculate minimum depths of the magma before eruption based on experimental studies of water solubility in rhyolite (Silver et al. 1990). Assuming a lithostatic load and a rock density of $2600 \mathrm{~kg} \mathrm{~m}^{-3}$, a value of $1.6 \mathrm{wt} . \%$ water suggests minimum depths of $c .0 .8 \mathrm{~km}$, whereas $3.3 \mathrm{wt} . \%$ $\mathrm{H}_{2} \mathrm{O}$ gives a minimum depth of $c .3 .1 \mathrm{~km}$. These depths are considered to be minimum values because they do not account for either a high-permeability, low-density edifice, or the presence of any $\mathrm{CO}_{2}$ that also may have been dissolved in the magma (Holloway \& Blank 1994; Dixon \& Stolper 1995). Significant prior $\mathrm{CO}_{2}$ loss is expected at depths considerably deeper than $3 \mathrm{~km}$, implying low $\mathrm{CO}_{2}$ contents in these magmas. However, magmas at deeper levels beneath the volcano may contain higher levels of $\mathrm{CO}_{2}$.

Taken together, these various lines of evidence indicate an evolved magma that resided at shallow levels $(\leqslant 3 \mathrm{~km})$ before the eruptions. The $\mathrm{H}_{2} \mathrm{O}$ and sulphur data indicate that magma degassing, and accumulation of a free gas phase, occurred within the plumbing system of the volcano before the eruptions, rationally implying that the magmas were fluid saturated during their residence at shallow levels. A logical point at which fluid saturation is achieved, although by no means the only possibility, is during magma ascent within the volcano.

One may thus reasonably envision the magmatic-hydrothermal system of Nevado del Ruiz as a plexus of small, interconnected reservoirs surrounded by a hydrothermal envelope; within this plexus, magmas periodically rise through a system of dykes and are stored. Depending on the initial volatile content of the 'primary' or 'deep' magma, volatile saturation is reached at a certain point, and the magma begins to degas. We now address the specific sequence of the degassing process beneath the volcano.

\section{A model of magmatic degassing at Nevado del Ruiz}

It is instructive to consider the various glasses in terms of their relative degrees of evolution. In this case, the usage is somewhat different from the conventional petrological concept, e.g. basalt v. rhyolite. As most of the glasses are rhyolitic in composition, the distinction is subtler, being based on small differences in bulk chemistry and volatile contents. For example, R0C melt inclusions in pyroxene and $103 \mathrm{~b}$ melt inclusions in plagioclase have comparatively high concentrations of $\mathrm{SiO}_{2}, \mathrm{H}_{2} \mathrm{O}$ and boron, and low concentrations of fluorine, chlorine and sulphur. We thus consider these samples to be highly evolved, meaning that they are both chemically differentiated (high $\mathrm{SiO}_{2}$ ) and degassed (low $\mathrm{Cl}, \mathrm{S})$. Yet if these samples are degassed, they present an apparent paradox of high $\mathrm{H}_{2} \mathrm{O}$ values coupled with low halogens and sulphur; this is discussed in detail below. In contrast, R0C melt inclusions in plagioclase exhibit a wide range of volatile contents. This variability may be the result of melt being trapped at different stages of magma evolution and transport.

Our proposed model consists of at least two stages, in which magma first rises through dykes from a deep reservoir (9$15 \mathrm{~km}$ ) and then ponds at its neutral buoyancy level. Because the magma follows a complicated plexus of crustal cracks, it will tend to pond in small reservoirs at different depths, rather than within a single larger reservoir. The model is illustrated in Figure 7. As a batch of magma ascends, it decompresses and loses volatiles such as $\mathrm{Cl}, \mathrm{S}, \mathrm{CO}_{2}$, and $\mathrm{H}_{2} \mathrm{O}$ by open-system degassing. Because the fluid-melt partition coefficient for chlorine increases with pressure (Shinohara et al. 1989), chlorine loss will tend to be enhanced at greater depths. The highly variable trends shown by the R0C plagioclase melt inclusions are consistent with this style of decompressive degassing. Conversely, the trends are not consistent with magma mixing because, as discussed above, the plagioclase melt inclusions are tightly clustered on the lower evolutionary trend defined by the major elements (Fig. 2).

The extent to which a magma rises will be partly determined by its buoyancy. This parameter is controlled by the magma's 


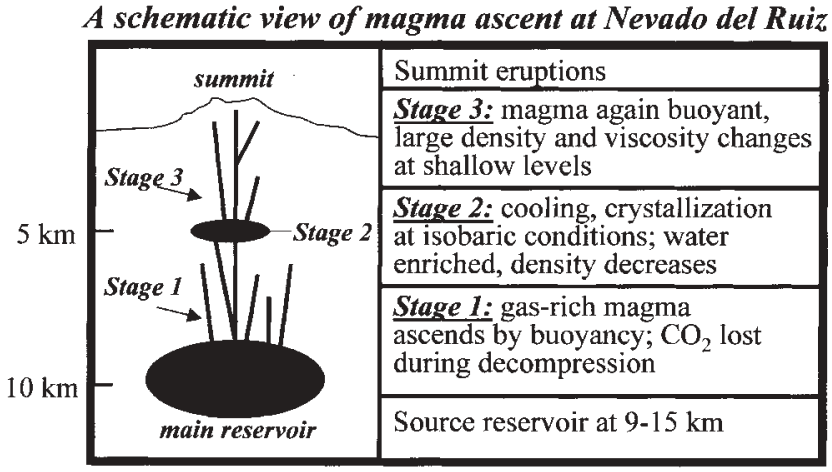

Fig. 7. A conceptual view of magma ascent and ponding beneath Nevado del Ruiz. Magma ascends from the source reservoir at $9-15 \mathrm{~km}$ through a plexus of cracks in the crust. Ponding occurs in permeable zones where magma attains its level of neutral buoyancy.

density, which is a function of composition, temperature, and dissolved water content. In terms of volatiles, a magma that is initially $\mathrm{CO}_{2}$ rich will have fundamentally different density and buoyancy compared with one that contains no $\mathrm{CO}_{2}$.

A $\mathrm{CO}_{2}$-rich, gas-saturated magma will lose most of its $\mathrm{CO}_{2}$ but little of its $\mathrm{H}_{2} \mathrm{O}$ during ascent and decompression. For such a magma, experimental studies have shown that water degassing is significantly less than that of carbon dioxide as pressure declines (Holloway \& Blank 1994; Dixon \& Stolper 1995) (Fig. 8). Because little water is lost, the magma's density will not change significantly, other factors being equal. Thus, the buoyancy of the magma is mainly a function of the initial water content, which in turn is controlled in large part by the amount of $\mathrm{CO}_{2}$ initially dissolved in the magma. If $\mathrm{CO}_{2}$ is high, then its $\mathrm{H}_{2} \mathrm{O}$ content will be comparatively low and its density high. As a result, the buoyancy will be relatively low, and the magma will tend to pond at deeper levels. If, on the other hand, $\mathrm{CO}_{2}$ is low, the water content will be higher, with a consequently lower density. The higher buoyancy will allow the magma to pond at shallower depths. In summary, the magma's buoyancy and ponding depth are determined to a large extent by the initial $\mathrm{CO}_{2}$ content at source.

Once ponding does occur, a gas-saturated $\mathrm{CO}_{2}$-bearing magma differentiates by crystallizing, while continuing to degas isobarically. The evolved R0C melt inclusions in pyroxene and $103 \mathrm{~b}$ melt inclusions in plagioclase probably are the result of magma ponding at shallow crustal levels beneath the volcano. At this point, both $\mathrm{H}_{2} \mathrm{O}$ and $\mathrm{SiO}_{2}$ are enriched. The high $\mathrm{SiO}_{2}$ values are the result of crystallization processes within the holding reservoir, whereas the high water contents are due to increased water solubility in the magma from degassing of $\mathrm{CO}_{2}$ at a given pressure, as shown in Figure 8. If only a small amount of $\mathrm{CO}_{2}$ remains when the magma ponds, then the dissolved water content of the magma can increase only by a small amount as $\mathrm{CO}_{2}$ is released, accompanied by correspondingly small decreases in magma density. If significant $\mathrm{CO}_{2}$ remains at the point of ponding, however, the amount of dissolved water can increase substantially as $\mathrm{CO}_{2}$ is degassed, with a large decline in magma density and viscosity. At this point, it is conceivable that the magma may again start to rise to even shallower depths (or erupt), as it is now water rich, less dense, less viscous, and more buoyant than previously.

In contrast, a gas-saturated magma that does not contain $\mathrm{CO}_{2}$ will be highly enriched in dissolved water ( $>6 \mathrm{wt} . \%)$ and very buoyant at depths of $9-15 \mathrm{~km}$. As it ascends and decompresses,

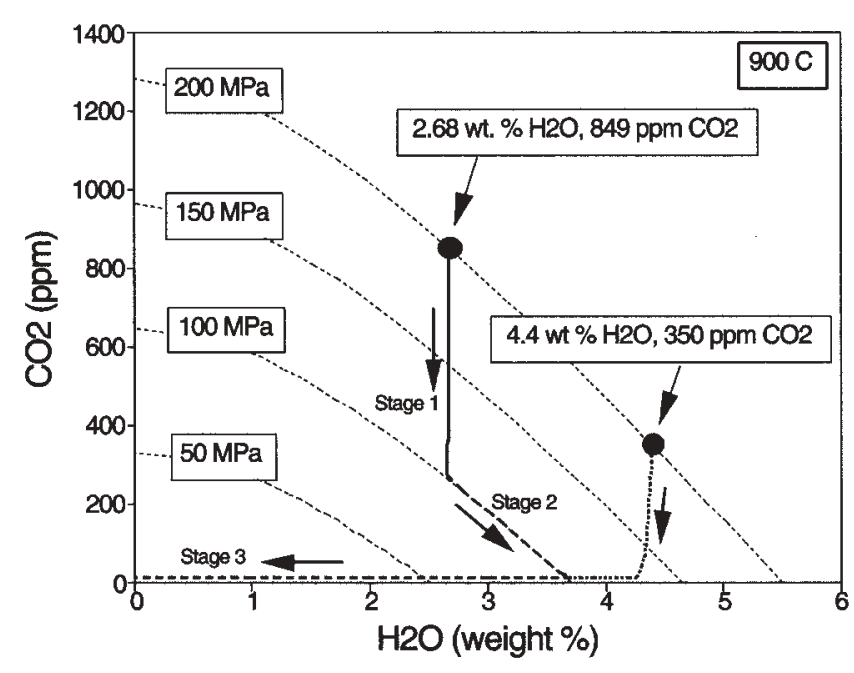

Fig. 8. Open-system degassing of $\mathrm{H}_{2} \mathrm{O}$ and $\mathrm{CO}_{2}$ during magma ascent and ponding, as shown by the bold dashed and dotted lines with arrows, superimposed on a plot of $\mathrm{H}_{2} \mathrm{O}-\mathrm{CO}_{2}$ solubility (fine dotted lines). For an

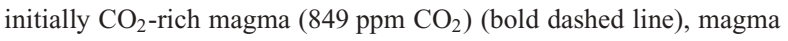
ascends and decompresses from 200 to $100 \mathrm{MPa}$ during Stage 1. At this stage, significant $\mathrm{CO}_{2}$ is lost by degassing, whereas the $\mathrm{H}_{2} \mathrm{O}$ concentration remains approximately constant. During Stage 2, the magma ponds at $100 \mathrm{MPa}$, resulting in increased $\mathrm{H}_{2} \mathrm{O}$ solubility in the magma as $\mathrm{CO}_{2}$ is driven off by isobaric degassing. Dissolved water contents increase accordingly from 2.66 to $3.71 \mathrm{wt} . \%$. During Stage 3, magma is again buoyant owing to its increased $\mathrm{H}_{2} \mathrm{O}$ content, and it ascends to shallower levels. At this point, significant water is lost by degassing. For a magma with $350 \mathrm{ppm} \mathrm{CO}_{2}$ initially (bold dotted line), the $\mathrm{CO}_{2}$ is purged rapidly from the magma during decompressive degassing, whereas $\mathrm{H}_{2} \mathrm{O}$ decreases slightly. If ponding occurs at pressures $<125 \mathrm{MPa}$, the magma cannot increase its $\mathrm{H}_{2} \mathrm{O}$ content during isobaric degassing, as no dissolved $\mathrm{CO}_{2}$ remains. Instead, the dissolved $\mathrm{H}_{2} \mathrm{O}$ content is buffered at a constant value. Modelling based on a program developed by Newman \& Lowenstern (2002).

the magma will lose $\mathrm{H}_{2} \mathrm{O}$ continuously, thereby driving up its density. None the less, the $\mathrm{H}_{2} \mathrm{O}$ concentration will remain elevated as the magma rises. Consequently, its continued buoyancy may permit the magma to either erupt or rise to very shallow levels before its density equals that of the surrounding rocks. If the magma ponds, there is no $\mathrm{CO}_{2}$ available to be driven off. The dissolved water content thus will remain buffered at a constant value, and the magma density will not change. In this case, the magma may have difficulty in regaining its buoyancy.

\section{Quantitative modelling of gas release during magma ascent and ponding}

We now model this degassing process at Nevado del Ruiz by considering changes in density and viscosity of the magma during its ascent, and during ponding (Fig. 9). We examine two scenarios in which gas saturation occurs at $200 \mathrm{MPa}$ : (1) a magma rich in $\mathrm{CO}_{2}$ and poor in $\mathrm{H}_{2} \mathrm{O}$ (2.7 wt.\% $\mathrm{H}_{2} \mathrm{O}, 849$ ppm $\mathrm{CO}_{2}$ ); (2) a magma comparatively rich in $\mathrm{H}_{2} \mathrm{O}$ and depleted in $\mathrm{CO}_{2}$ (4.4 wt.\% $\mathrm{H}_{2} \mathrm{O}, 350$ ppm $\mathrm{CO}_{2}$ ). We make some simplifying assumptions to highlight the effect of water content on the physical properties of the magma. First, we assume that the magma degassing process is open, meaning that gas and bubbles are lost from the magma during degassing. Second, we neglect density and viscosity changes caused by the physical presence of 
crystals and bubbles in the magmatic liquid. Although these factors clearly influence the density and viscosity, we ignore them to emphasize the changes caused by gain or loss of water in the magma. The magma density is calculated according to the methods of Ghiorso \& Sack (1995) and Mastin \& Ghiorso (2000); this approach uses the bulk composition, water content, pressure, and temperature of the magma to calculate the density. The magma viscosity is calculated according to Hess \& Dingwell (1996), who considered water contents and temperatures of leucogranite (rhyolite) melts.

\section{(a) Gas saturation @ $200 \mathrm{MPa}, 900^{\circ} \mathrm{C}$} Initial $\mathrm{H} 2 \mathrm{O}=2.68$ wt. $\%, \mathrm{CO} 2=849 \mathrm{ppm}$

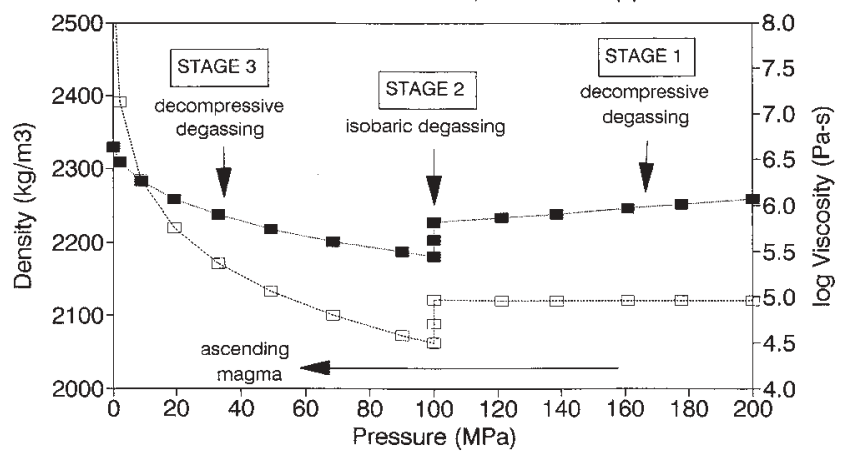

(b) Gas saturation @ $200 \mathrm{MPa}, 900^{\circ} \mathrm{C}$ Initial $\mathrm{H} 2 \mathrm{O}=4.4$ wt. $\%, \mathrm{CO} 2=350.5 \mathrm{ppm}$

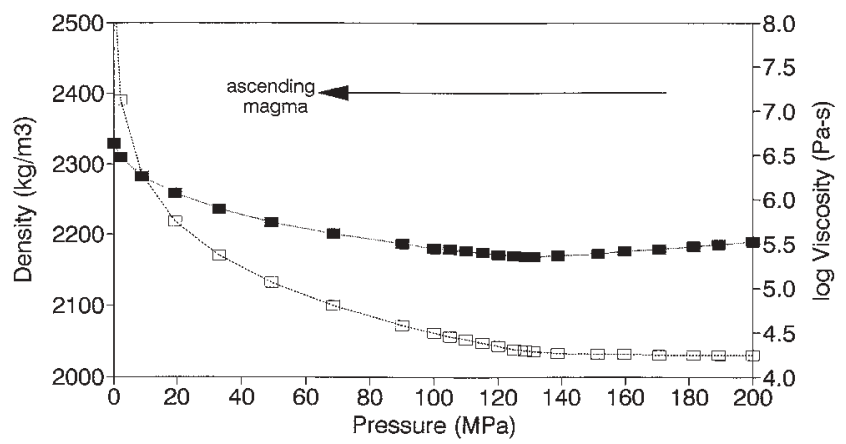

- Density -......... Viscosity

Fig. 9. Two schematic models of density and viscosity of a magma beneath Nevado del Ruiz. Degassing is considered to be an open-system process, the gas being expelled from the magma to the wallrocks, the hydrothermal system, and the surface. (a) For an initially $\mathrm{CO}_{2}$-rich magma, decompressive degassing from 200 to $100 \mathrm{MPa}$ during Stage 1 causes $\mathrm{CO}_{2}$ to be liberated, and its density and viscosity exhibit small changes. The magma then stalls and ponds at $100 \mathrm{MPa}$; cooling and crystallization cause continued degassing, resulting in $\mathrm{CO}_{2}$ loss and increased $\mathrm{H}_{2} \mathrm{O}$, which is dissolved in the magma. Beyond a certain point, the magma becomes buoyant and continues to rise during Stage 3. Large decreases in water solubility cause significant water loss from the magma at shallow depths. As a result, the magma's density and viscosity increase significantly. (b) With less $\mathrm{CO}_{2}$ initially, the magma contains generally higher water contents; this enhances its buoyancy and allows it to rise to shallow levels. If magma ponds, its water content will be buffered at a constant value, preventing the density and viscosity from changing much. Magma densities and viscosities calculated following Ghiorso \& Sack (1995), Hess \& Dingwell (1996) and Mastin \& Ghiorso (2000).
Our modelling of the $\mathrm{CO}_{2}$-rich magma shows changes in density and viscosity during three stages as it (1) rises and decompresses from a pressure of $200 \mathrm{MPa}$ to $100 \mathrm{MPa}$, (2) ponds for a period of time at $100 \mathrm{MPa}$, and (3) subsequently rises and decompresses further from $100 \mathrm{MPa}$ to the surface (0 MPa) (Fig. 9a). During Stage 1, density and viscosity exhibit small changes as a result of little water loss at elevated $\mathrm{CO}_{2}$ contents, and the magma ponds at $100 \mathrm{MPa}$ at its neutral density level of $2227 \mathrm{~kg}$ $\mathrm{m}^{-3}$. During Stage 2, isobaric crystallization owing to ponding causes the remaining $\mathrm{CO}_{2}$ in the melt to be degassed, thereby enhancing $\mathrm{H}_{2} \mathrm{O}$ solubility in the melt. As a result, density and viscosity both decrease, and the magma becomes buoyant and mobile. During Stage 3, magma ascent at low pressures causes significant decompressive exsolution of $\mathrm{H}_{2} \mathrm{O}$, resulting in comparatively large increases in density and viscosity.

In contrast, modelling the $\mathrm{CO}_{2}$-poor magma indicates a different sequence by which the magma ascends (Fig. 9b). The density and viscosity do not vary much from the point of gas saturation at $200 \mathrm{MPa}$ to about $130 \mathrm{MPa}$. Beyond this point, both parameters begin to increase, first slowly and then rapidly. This is because $\mathrm{CO}_{2}$ is depleted from the magma at $125-130 \mathrm{MPa}$; as a result, the water content is no longer buffered by $\mathrm{CO}_{2}$ and starts to decrease, driving up the density and viscosity. If magma ponds in this situation, it cannot increase its water content by isobaric crystallization; instead, the amount of $\mathrm{H}_{2} \mathrm{O}$ is buffered at a constant value, and the density and viscosity do not change. On the other hand, the initially water-rich nature of the magma at $200 \mathrm{MPa}$ means that it is more buoyant and can rise to generally higher levels than in the case of the $\mathrm{CO}_{2}$-rich, $\mathrm{H}_{2} \mathrm{O}$-poor magma depicted in Figure 9a.

These two examples demonstrate, in a general fashion, how magmas might rise and pond beneath the volcano. Clearly, there is a continuum of different possibilities in terms of how the magma is transported through the crust to the surface, and a single stage or multiple stages can be envisaged. None the less, the largest changes of density and viscosity as a result of decompressive degassing occur at shallow levels where water solubility can vary substantially. Therefore, we suggest that ponding may be facilitated at these shallow depths, where the magma density is increased substantially, and the magma becomes sluggish from its enhanced viscosity owing to water loss. The water loss also will induce crystallization (Blundy \& Cashman 2001), which will contribute to the increasingly viscous nature of the magma. On the other hand, degassing is not necessarily a purely open-system process. In other words, as degassing proceeds, free gas may be retained in the magma in the form of bubbles. Bubble retention is favoured in the latter part of Stage 3, when the magma is at shallow levels and has a high viscosity, inhibiting bubble release. The result is a magma that is highly buoyant yet very viscous, conditions that are conducive to an explosive eruption.

In summary, this model explains the apparent contradiction, observed in the R0C glasses, between low $\mathrm{Cl}$ and $\mathrm{S}$ on the one hand, and high $\mathrm{H}_{2} \mathrm{O}$ and $\mathrm{SiO}_{2}$ on the other hand, by invoking a multistage evolution of magma ascent and ponding. The model is fully consistent with earlier views of the magmatic-hydrothermal system at Nevado del Ruiz (e.g. Giggenbach et al. 1990) but proposes that the magmas erupted in 1985 and 1989 may have resided in one or more vertically extensive, volumetrically modest reservoirs at shallow depths. Notably, the model implies that much if not most of the degassing occurs before eruption, rather than during eruption, which is consistent with the observation that measured volatile contents (except for water) are similar between melt inclusions and matrix glasses. Eruptions serve to 
stir up magmas that have ponded at different levels, so that they are found intimately mingled and mixed in the eruptive products. As discussed above, some matrix glasses have higher sulphur contents than do their contained melt inclusions, supporting the idea of tapping of magmas from various depths. The water variability that is observed in the melt inclusions is thus the consequence of three major processes: (1) decompressive degassing; (2) $\mathrm{H}_{2} \mathrm{O}$ solubility linked to $\mathrm{CO}_{2}$ contents in the magma; (3) syneruptive mixing of magmas at various depths. Finally, the model can serve as a useful paradigm for other similar subduction volcanoes, to better understand magma evolution and degassing in this class of explosive volcanic systems.

The presence of faults within the edifice of the volcano may influence the transport and degassing of the magma. Muñoz (1992) has shown that the summit area of the volcano is intersected by two regional fault systems: the Palestina fault, trending NE-SW, and the Termales-Villamaria fault, trending NW-SE. The summit region also is characterized by shallow Bouguer gravity and seismic velocity lows. Swarms of highfrequency seismic events were detected between 1985 and 1990. Muñoz (1992) has interpreted these features as evidence of magma, a fracture zone, water-filled cracks, and/or zones of altered rocks.

Faults provide pathways, such as dykes, along which magma transport is facilitated. Furthermore, the fault zones should aid the degassing process during magma ascent, as the gas will have a means to escape into the wallrocks or to the surface. Thus, the faults should promote open-system degassing. As a final point, if magma encounters a low-density permeable zone during its rise along a fault, the magma may spread laterally and pond as a sill within this zone, if the magma's buoyancy and viscosity are not too high. In summary, fault structures are certainly present, and may play an important role in the evolution, transport, and degassing of magma beneath Nevado del Ruiz.

\section{The problem of boron at Nevado del Ruiz}

Subduction volcanoes generally show enrichments of boron in their eruptive products when compared with volcanoes in other tectonic environments. Traditionally, the high levels of boron are ascribed to a contribution from underlying subducted sediments or altered oceanic crust (Tera et al. 1986; Morris et al. 1990; Ryan et al. 1996; Ishikawa \& Tera 1999). As the subducted slab descends, it dehydrates, liberating a fluid that is enriched in boron and other soluble elements. This fluid subsequently causes melting in the overlying mantle wedge, producing arc magmas that contain high levels of boron. More recent studies (e.g. Straub \& Layne 2002) have suggested additional details to this process. However, a general consensus remains that boron enrichment in most subduction magmas is predominantly a source phenomenon. Strong evidence for this source effect is the positive correlation of $\mathrm{B}$ and $\mathrm{B} / \mathrm{Be}$ with ${ }^{10} \mathrm{Be} /{ }^{9} \mathrm{Be}$ in arc volcanic rocks (Morris et al. 1990). However, very little is understood of the potential role of other, shallower processes in enriching or modifying the boron contents of arc magmas. In this regard, the recent Nevado del Ruiz eruptions provide an instructive example.

For the Nevado del Ruiz samples, boron exhibits unusual enrichment and variability within both melt inclusions and matrix glasses. As noted above, even melt inclusions within the same phenocryst can have highly variable boron concentrations. The $\mathrm{B} / \mathrm{Be}$ ratio exhibits large variability at a given $\mathrm{SiO}_{2}$ or $\mathrm{Be}$ content (Fig. 5d). Thus, the variations cannot be purely the result of partial melting or fractional crystallization, as $\mathrm{B}$ and $\mathrm{Be}$ behave in a similar fashion in these cases (Stix \& Layne 1996;
Brenan et al. 1998). For example, in epicontinental silicic magmas, the $\mathrm{B} / \mathrm{Be}$ ratio typically remains constant at values of 2-3 during crystallization as both $\mathrm{B}$ and $\mathrm{Be}$ are enriched as incompatible elements. Further, at Nevado del Ruiz, boron does not show simple correlations with volatile elements such as sulphur or chlorine, or with the $\mathrm{Cl} / \mathrm{F}$ ratio, indicating that degassing processes do not control the boron variability. Neither does boron show trends that would indicate magma mixing. For example, whereas there are large boron variations in the R0C plagioclase melt inclusions (Fig. 5c), the melt inclusions show little or no evidence for magma mixing on major element plots (Fig. 2).

If the high boron concentrations in the Nevado del Ruiz magmas were solely the result of a source effect (e.g. partial melting of a hydrated mantle slab), then the melt inclusions would be expected to have uniform boron concentrations. The significant heterogeneity we have documented, both for melt inclusions found in different crystals and for those in the same crystal, strongly suggests that the boron enrichment and variability are predominantly due to higher-level processes in the crust. The two most likely processes are (1) selective assimilation of sedimentary evaporitic rocks (i.e. borates) by the magma, and (2) interaction of the magma with a deep hydrothermal brine that is enriched in boron. Melson et al. (1990) have documented the presence of sedimentary xenoliths, some of which are anhydrite bearing, in the Nevado del Ruiz eruptive products. Fournelle (1990) has observed trace amounts of anhydrite in pumices from the November 1985 eruption and has noted the presence of evaporite deposits near the volcano. Globally, Palmer (1991) has documented high boron concentrations in hydrothermal fluids derived from non-marine evaporites that contain borate minerals. Sturchio et al. (1988) and Giggenbach et al. (1990) have shown that some of the hydrothermal springs on Nevado del Ruiz are enriched in boron, suggesting the possibility of a deep hydrothermal parent brine. Although the origin of a non-source boron component is admittedly speculative, it is not realistic to ascribe the boron variations at Ruiz simply to a source effect, as is generally done for subduction volcanoes. The evidence for shallow-level magma evolution, as discussed above, and the highly evolved nature of the glasses together argue for a comparatively shallow-level process or processes that have controlled the boron distributions at Nevado del Ruiz.

Metrich et al. (1998) also have documented boron heterogeneity in melt inclusions from the Vulsini district, Italy, and ascribed the variations to a mantle partial melting effect. In this case, however, the inclusions were primitive basaltic melts with $\mathrm{Mg}$ numbers $>0.70$.

A fundamental problem with source enrichment of boron during subduction is that most of the boron is removed from the slab by low-temperature dehydration reactions before reaching depths appropriate for slab melting (Leeman 1996; Ryan et al. 1996). There is thus an implicit deficit of boron in the mantle wedge beneath arc volcanoes. To deal with this problem, it has been suggested that the shallow, boron-rich mantle wedge is dragged to greater depths by subduction, where it is then deep enough to generate arc magmas (Brenan et al. 1998). Alternatively, Bebout et al. (1999) have proposed that 'warm' subduction zones mobilize boron in the fore-arc, with resulting boron depletion in the magmatic arc, whereas 'cool' subduction zones are able to transport boron to deeper levels, where it is then released into the mantle wedge and enriched in the magmatic arc. Straub \& Layne (2002) extended these ideas to model both boron and boron isotope systematics of the Izu arc volcanic front. However, source processes alone remain insufficient to 
model the variations of B observed at Nevado del Ruiz, where we propose that a portion of the boron addition must occur at higher levels in the crust by melt assimilation, or hydrothermal input from circulating fluids within the volcanic edifice.

\section{Concluding remarks}

The magmatic-hydrothermal system of Nevado del Ruiz is the result of a variety of processes that have contributed to its present-day character. Subsequent to partial melting within the mantle wedge above the subducting Nazca plate, the magmas appear to have crystallized, degassed, assimilated, and mingled rather extensively as they ascended through the crust before eruption.

The trends defined by the major elements are indicative of two continuously evolving magmas, which interacted and mingled at times. The low water contents strongly suggest that the erupted tephras were derived from a shallow magma reservoir or reservoirs. The water contents appear to be controlled by reservoir depth, by decompression during magma ascent, and by the amount of $\mathrm{CO}_{2}$ present in the magma. More generally, the low water values are consistent with other evidence that indicates that the magmas resided at shallow depths before being erupted. This shallow residence allowed the magma to degas extensively before eruption, explaining the large amounts of passive volcanic degassing observed from 1985 to 1990 and beyond (Williams et al. 1990) and the extensive hydrothermal system present beneath the volcano (Sturchio et al. 1988; Giggenbach et al. 1990). The model proposed here, which is clearly not unique to Nevado del Ruiz, is one of magma ascent and ponding at high levels in the crust, accompanied by degassing, crystallization and assimilation. There is good evidence that boron was assimilated at shallow levels, implying that a boron-rich mantle was not the only source of this element in the Nevado del Ruiz magmas.

Our sequential model of magma ascent and ponding provides a viable mechanism to transport magmas from deep levels to the surface where they erupt. The model implies that a magma's buoyancy changes during its lifetime within upper regions of the crust. For a $\mathrm{CO}_{2}$-rich magma, the model further implies that the style of degassing will depend upon whether the magma is ascending or ponded. During initial ascent and decompression, mostly $\mathrm{CO}_{2}$ is degassed, particularly if open-system degassing prevails. The loss of $\mathrm{CO}_{2}$ will buffer the magma's density to a point where it stagnates and ponds at a level of neutral buoyancy. Once the gas-saturated magma is ponded and retained in a holding reservoir, it will cool and crystallize, causing further degassing. However, the nature of this isobaric degassing is fundamentally different from that which occurs during decompression. In this case, $\mathrm{CO}_{2}$ is degassed gradually whereas dissolved $\mathrm{H}_{2} \mathrm{O}$ is enriched in the magma as a result of increased $\mathrm{H}_{2} \mathrm{O}$ solubility as $\mathrm{CO}_{2}$ is lost. As $\mathrm{H}_{2} \mathrm{O}$ builds up, density and viscosity decrease to a stage where the magma may again be sufficiently buoyant and mobile to rise further. If the magma rises rapidly, it may erupt. If it rises slowly, it will become dense and viscous, thereby ponding and freezing at a shallow depth. Faults provide additional pathways, such as dykes, for magma transport and also may help to degas the magma during its ascent.

Finally, our model helps shed light on the problems of excess sulphur degassing from subduction volcanoes and $\mathrm{SO}_{2}$ fractionation at the tops of eruption columns (Rose et al. 2000). A primary conclusion from our work is that magmas beneath volcanoes such as Nevado del Ruiz release significant gas during periods of quiescence. If the magmatic-hydrothermal system is sealed, the released gas can accumulate under the volcano, rather than be released directly into the atmosphere. The amount of sulphur and other gases lost by the magma at this stage probably depends upon the magma's ascent rate, its ponding in a holding reservoir, and the dimensions of the reservoir. Degassing will be enhanced by sluggish magma ascent, prolonged ponding, and a complex reservoir system with large surface area. Once an eruption is initiated, the seal ruptures, suddenly releasing massive amounts of gas, which have been accumulating within the plumbing system of the volcano.

Reviews by J. Blundy and W. Rose substantially improved the paper and are gratefully acknowledged. We are most grateful to $\mathrm{H}$. Westrich, who supplied water standards, and J.-P. Bourque, who prepared the grain mounts. Discussions with J. Dixon helped improve our ideas on magma degassing. We thank J. Lowenstern for allowing us to use a prepublication version of an $\mathrm{H}_{2} \mathrm{O}-\mathrm{CO}_{2}$ solubility program. Most of the SIMS analyses were accomplished when G.D.L. was an NSERC Postdoctoral Fellow in the MIT-Harvard-Brown Ion Microprobe Facility at MIT. This work was funded with grants to J.S. by the Natural Sciences and Engineering Research Council of Canada and by the Fonds pour la formation de chercheurs et l'aide à la recherche (Québec).

\section{References}

Banks, N.G., Carvajal, C., Mora, H. \& Tryggvason, E. 1990. Deformation monitoring at Nevado del Ruiz, Colombia-October 1985-March 1988. Journal of Volcanology and Geothermal Research, 41, 269-295.

Bebout, G.E., Ryan, J.G., Leeman, W.P. \& Bebout, A.E. 1999. Fractionation of trace elements by subduction-zone metamorphism-effect of convergentmargin thermal evolution. Earth and Planetary Science Letters, 171, 63-81.

Blank, J.G. \& Brooker, R.A. 1994. Experimental studies of carbon dioxide in silicate melts: solubility, speciation, and stable carbon isotope behavior. In: Carroll, P.R. \& Holloway, J.R. (eds) Volatiles in magmas. Mineralogical Society of America, Reviews in Mineralogy, 30, 157-186.

Blundy, J. \& Cashman, K. 2001. Ascent-driven crystallization of dacite magmas at Mount St Helens, 1980-1986. Contributions to Mineralogy and Petrology, 140, 631-650.

Brenan, J.M., Ryerson, F.J. \& Shaw, H.F. 1998. The role of aqueous fluids in the slab-to-mantle transfer of boron, beryllium, and lithium during subduction: experiments and models. Geochimica et Cosmochimica Acta, 62, $3337-3347$.

Dixon, J.E. \& STOLPer, E.M. 1995. An experimental study of water and carbon dioxide solubilities in mid-ocean ridge basaltic liquids. Part II: applications to degassing. Journal of Petrology, 36, 1633-1646.

Dunbar, N.W. \& Hervig, R.L. 1992a. Petrogenesis and volatile stratigraphy of the Bishop Tuff: evidence from melt inclusion analysis. Journal of Geophysical Research, 97, 15129-15150.

Dunbar, N.W. \& Hervig, R.L. 1992b. Volatile and trace element composition of melt inclusions from the Lower Bandelier Tuff: implications for magma chamber processes and eruptive style. Journal of Geophysical Research, 97, $15151-15170$.

Eichelberger, J.C., Carrigan, C.R., Westrich, H.R. \& Price, R.H. 1986. Nonexplosive silicic volcanism. Nature, 323, 598-602.

FinK, J.H., Anderson, S.W. \& Manley, C.R. 1992. Textural constraints on effusive silicic volcanism: beyond the permeable foam model. Journal of Geophysical Research, 97, 9073-9083.

Fischer, T.P., Morrissey, M.M., Calvache V., M.L., Gómez M., D., Torres C., R., Stix, J., Williams, S.N. \& Williams, S.N. 1994. Correlations between $\mathrm{SO}_{2}$ flux and long-period seismicity at Galeras volcano, Colombia. Nature, 368, $135-137$.

Fournelle, J. 1990. Anhydrite in Nevado del Ruiz November 1985 pumice: relevance to the sulfur problem. Journal of Volcanology and Geothermal Research, 42, 189-201.

GHIORSO, M.S. \& SACK, R.O. 1995. Chemical mass transfer in magmatic processes IV: a revised and internally consistent thermodynamic model for the interpolation and extrapolation of liquid-solid equilibria in magmatic systems at elevated temperatures and pressures. Contributions to Mineralogy and Petrology, 119, 197-212.

Giggenbach, W.F., Garcia P., N., Londoño C., A., Rodriguez V., L., Rojas G., N. \& Calvache V., M.L. 1990. The chemistry of fumarolic vapor and thermal-spring discharges from the Nevado del Ruiz volcanic-magmatichydrothermal system, Colombia. Journal of Volcanology and Geothermal Research, 42, 13-39. 
Gourgaud, A. \& Thouret, J.-C. 1990. Magma mixing and petrogenesis of the 13 November 1985 eruptive products at Nevado del Ruiz (Colombia). Journal of Volcanology and Geothermal Research, 41, 79-96.

Hess, K.-U. \& Dingwell, D.B. 1996. Viscosities of hydrous leucogranitic melts: a non-Arrhenian model. American Mineralogist, 81, 1297-1300.

Holloway, J.R. \& Blank, J.G. 1994. Application of experimental results to C-O-H species in natural melts. In: Carroll P.R. \& Holloway J.R. (eds) Volatiles in magmas. Mineralogical Society of America, Reviews in Mineralogy, 30, 187-230.

IshiKawa, T. \& Tera, F. 1999. Two isotopically distinct fluid components involved in the Mariana arc: evidence from $\mathrm{Nb} / \mathrm{B}$ ratios and $\mathrm{B}, \mathrm{Sr}, \mathrm{Nd}$, and $\mathrm{Pb}$ isotope systematics. Geology, 27, 83-86.

JAUPART, C. 1998. Gas loss from magmas through conduit walls during eruption. In: Gilbert, J.S.. \& SPARKs, R.S.J. (eds) The Physics of Explosive Volcanic Eruptions. Geological Society, London, Special Publications, 145, 73-90.

Krueger, A.J., Walter, L.S., Schnetzler, C.C. \& Doiron, S.D. 1990. TOMS measurement of the sulfur dioxide emitted during the 1985 Nevado del Ruiz eruptions. Journal of Volcanology and Geothermal Research, 41, 7-15.

LeEman, W.P. 1996. Boron and other fluid-mobile elements in volcanic arc lavas: implications for subduction processes. In: Bевоut, G.E., Scholl, D.W., Kirby, S.H. \& PlatT, J.P. (eds) Subduction top to bottom. American Geophysical Union, Geophysical Monographs, 96, 263-268.

Martinelli, B. 1990. Analysis of seismic patterns observed at Nevado del Ruiz volcano, Colombia during August-September 1985. Journal of Volcanology and Geothermal Research, 41, 297-314

Massol, H. \& JAUPART, C. 1999. The generation of gas overpressure in volcanic eruptions. Earth and Planetary Science Letters, 166, 57-70.

Mastin, L.G. \& Ghiorso, M.S. 2000. A Numerical Program for Steady-state Flow of Magma-Gas Mixtures through Vertical Eruptive Conduits. US Geological Survey Open File Report 00-209.

McMillan, P.F. 1994. Water solubility and speciation models. In: Carroll, P.R. \& Holloway, J.R. (eds) Volatiles in magmas. Mineralogical Society of America, Reviews in Mineralogy, 30, 131-156.

Melson, W.G. \& Allan, J.F. ET AL. 1990. Water contents, temperatures and diversity of the magmas of the catastrophic eruption of Nevado del Ruiz, Colombia, November 13, 1985. Journal of Volcanology and Geothermal Research, 41, 97-126.

Metrich, N., Joron, J.-L. \& Berthier, B. 1998. Occurrence of boron-rich potassic melts in the Vulsini Volcanic District, Italy: evidence from melt inclusions. Geochimica et Cosmochimica Acta, 62, 507-514.

Morris, J.D., Leeman, W.P. \& Tera, F. 1990. The subducted component in island arc lavas: constraints from $\mathrm{Be}$ isotopes and B-Be systematics. Nature, 344, $31-36$.

MuÑoz, F.A. 1992. Local earthquake tomography for lateral velocity variations and hypocenters at Nevado del Ruiz volcano-Colombia. M.S. thesis, Arizona State University, Tempe.

Naranjo, J.L., Sigurdsson, H., Carey, S.N. \& Fritz, W. 1986. Eruption of the Nevado del Ruiz volcano, Colombia, on 13 November 1985: tephra fall and lahars. Science, 233, 961-963.

Newman, S. \& Lowenstern, J.B. 2002. VolatileCalc: a silicate melt- $\mathrm{H}_{2} \mathrm{O}$ $\mathrm{CO}_{2}$ solution model written in Visual Basic for excel. Computers and Geosciences, 28, 597-604.

Nieto E., A.H., Brandsdóttir, B. \& Muñoz C., F. 1990. Seismicity associated with the reactivation of Nevado del Ruiz, Colombia, July 1985-December 1986. Journal of Volcanology and Geothermal Research, 41, 315-326.

PALMER, M.R. 1991. Boron isotope systematics of hydrothermal fluids and tourmalines: a synthesis. Chemical Geology, 94, 111-121.

Rose, W.I., Bluth, G.J.S. \& ERNST, G.G.J. 2000. Integrating retrievals of volcanic cloud characteristics from satellite remote sensors: a summary. Philosophical Transactions of the Royal Society of London, Series A, 358, 1585-1606.
Ryan, J., Morris, J., Bebout, G. \& Leeman, B. 1996. Describing chemical fluxes in subduction zones: insights from depth-profiling studies of arc and forearc rocks. In: Bebout, G.E., Scholl, D.W., Kirby, S.H. \& Platt, J.P. (eds) Subduction top to bottom. American Geophysical Union, Geophysical Monographs, 96, 263-268.

Schaefer, S.J. 1995. Nevado del Ruiz volcano, Colombia: magmatic system and evolution. Ph.D. thesis, Arizona State University, Tempe.

Shinohara, H., Iryama, J.T. \& Matsuo, S. 1989. Partition of chlorine compounds between silicate melt and hydrothermal solutions: I. partition of $\mathrm{NaCl}-\mathrm{KCl}$. Geochimica et Cosmochimica Acta, 53, 2617-2630.

Sigurdsson, H., Carey, S., Palais, J.M. \& Devine, J. 1990. Pre-eruption compositional gradients and mixing of andesite and dacite magma erupted from Nevado del Ruiz volcano, Colombia in 1985. Journal of Volcanology and Geothermal Research, 41, 127-151.

Silver, L.A., Ihinger, P.D. \& Stolper, E. 1990. The influence of bulk composition on the speciation of water in silicate glasses. Contributions to Mineralogy and Petrology, 104, 142-162.

Stix, J. \& Layne, G.D. 1996. Gas saturation and evolution of volatile and light lithophile elements in the Bandelier magma chamber between two calderaforming eruptions. Journal of Geophysical Research, 101, 25181-25196.

Stix, J., Torres C., R., Narvaez M., L., Cortés J., G.P., Raigosa A., J., Gómez M., D. \& Castonguay, R. 1997. A model of vulcanian eruptions at Galeras volcano, Colombia. Journal of Volcanology and Geothermal Research, 77 $285-303$.

Straub, S.M. \& Layne, G.D. 2002. The systematics of boron isotopes in Izu arc front volcanic rocks. Earth and Planetary Science Letters, 198, 25-39.

Sturchio, N.C., Williams, S.N., García P., N. \& Londoño C., A. 1988. The hydrothermal system of Nevado del Ruiz volcano, Colombia. Bulletin of Volcanology, 50, 399-412.

Tera, F., Brown, L., Morris, J., Sacks, S., Klein, J. \& Middleton, R. 1986 Sediment incorporation in island-arc magmas: inferences from ${ }^{10} \mathrm{Be}$. Geochimica et Cosmochimica Acta, 50, 535-550.

Vatin-Pérignon, N., Goemans, P., Oliver, R.A. \& Parra Palacio, E. 1990. Evaluation of processes for the products of the Nevado del Ruiz volcano, Colombia from geochemical and petrological data. Journal of Volcanology and Geothermal Research, 41, 153-176.

Wallace, P.J., Anderson, A.T. JR \& Davis, A.M. 1999. Gradients in $\mathrm{H}_{2} \mathrm{O}, \mathrm{CO}_{2}$, and exsolved gas in a large-volume silicic magma system: interpreting the record preserved in melt inclusions from the Bishop Tuff. Journal of Geophysical Research, 104, 20097-20122.

Webster, J.D. 1990. Partitioning of $\mathrm{F}$ between $\mathrm{H}_{2} \mathrm{O}$ and $\mathrm{CO}_{2}$ fluids and topaz rhyolite melt. Contributions to Mineralogy and Petrology, 104, 424-438.

Webster, J.D. 1992a. Fluid-melt interactions involving Cl-rich granites: experimental study from 2 to 8 kbar. Geochimica et Cosmochimica Acta, 56, 659-678.

WeBster, J.D. 1992b. Water solubility and chlorine partitioning in Cl-rich granitic systems: effects of melt composition at $2 \mathrm{kbar}$ and $800{ }^{\circ} \mathrm{C}$. Geochimica et Cosmochimica Acta, 56, 679-687.

WiLliams, S.N. 1987. Nevado del Ruiz volcano, Colombia: the November 1985 eruption and related events. Journal of Volcanology and Geothermal Research, 33, 355-360

Williams, S.N. \& Meyer, H. 1988. A model of Nevado del Ruiz volcano, Colombia. EOS Transactions, American Geophysical Union, 69, 1554-1566.

Williams, S.N., Sturchio, N.C., Calvache V., M.L., Mendez F., R., Londoño C., A. \& García P., N. 1990. Sulfur dioxide from Nevado del Ruiz volcano, Colombia: total flux and isotopic constraints on its origin. Journal of Volcanology and Geothermal Research, 42, 53-68.

WILSON, S.D.R. 1998. A mechanism for the lateral transport of gas bubbles in silicic lava rising in a vertical conduit. Earth and Planetary Science Letters, 156, 13-18. 